\title{
Article \\ Standing Biomass, Dry-Matter Production, and Nutrient Demand of Tenera Oil Palm
}

\author{
Cheah See Siang ${ }^{1, *(\mathbb{D})}$, Siti Aishah Abd Wahid ${ }^{1}$ and Christopher Teh Boon Sung ${ }^{2, *(D)}$ \\ 1 Sime Darby Plantation Research Sendirian Berhad, Banting 42700, Malaysia; \\ sitiaishah.abdwahid@simedarbyplantation.com \\ 2 Department of Land Management, Faculty of Agriculture, Universiti Putra Malaysia, Serdang 43400, Malaysia \\ * Correspondence: cheah.see.siang@nbpol.com (C.S.S.); chris@upm.edu.my (C.T.B.S.); \\ Tel.: +60-126-330-520 (C.T.B.S.)
}

check for updates

Citation: Siang, C.S.; Wahid, S.A.A.; Sung, C.T.B. Standing Biomass, Dry-Matter Production, and Nutrient Demand of Tenera Oil Palm. Agronomy 2022, 12, 426. https:// doi.org/10.3390/agronomy12020426

Academic Editors: Othmane Merah, Purushothaman Chirakkuzhyil Abhilash, Magdi T. Abdelhamid, Hailin Zhang and Bachar Zebib

Received: 24 December 2021

Accepted: 25 January 2022

Published: 9 February 2022

Publisher's Note: MDPI stays neutral with regard to jurisdictional claims in published maps and institutional affiliations.

Copyright: (C) 2022 by the authors. Licensee MDPI, Basel, Switzerland. This article is an open access article distributed under the terms and conditions of the Creative Commons Attribution (CC BY) license (https:// creativecommons.org/licenses/by/ $4.0 /)$.

\begin{abstract}
Recent advances in oil-palm breeding and agronomic practices may have influenced the dry-matter production and nutrient demand of tenera oil palm since the last comprehensive studies published some three decades ago. This has raised concerns, since updated knowledge of nutrient requirements at various stages of oil palm growth is essential for formulating fertilizer recommendations that meet agronomic, economic, and environmental objectives. We therefore filled in this knowledge gap with the objective to quantify the standing biomass, dry-matter production, and nutrient demand of tenera oil palm of different ages, grown under current agronomic practices. Tenera palms were sampled at 12, 29, 48, 88, 133, 209, and 238 months since nursery planting and separated into spear leaves, leaflets, rachis, petiole, leaf bases, cabbage, trunk, bole, and roots attached to bole for determination of dry weights and nutrient contents. Fruit bunches were harvested, with dry weights and nutrient contents of ripe bunches determined. Annual dry-matter production was calculated from dry weights of different plant parts, and together with nutrient concentrations determined in these plant parts and fruit bunches, annual nutrient demand was calculated. Excluding roots, the total standing vegetative biomass increased almost linearly from $1.3 \mathrm{~kg} \mathrm{palm}^{-1}$ at 12 months old to $808.6 \mathrm{~kg} \mathrm{palm}^{-1}$ at 238 months old. Whole-palm dry-matter production increased with palm age but at a decreasing rate, from $1.5 \mathrm{~kg} \mathrm{palm}^{-1}$ year $^{-1}$ at 12 months old to $285.5 \mathrm{~kg} \mathrm{palm}^{-1}$ year $^{-1}$ after 133 months, with little increase thereafter. The maximum rates of nutrient demand occurred after 209 months, coinciding with peak production of fruit bunches-except for K, which occurred at month 88 when vegetative growth demand for $\mathrm{K}$ peaked. Annual gross amounts of nutrients required to produce $25 \mathrm{t}$ fresh fruit bunches ha ${ }^{-1}$ were $1.99 \mathrm{~kg} \mathrm{~N}, 0.28 \mathrm{~kg} \mathrm{P}, 3.94 \mathrm{~kg} \mathrm{~K}, 0.42 \mathrm{~kg} \mathrm{Mg}, 0.99 \mathrm{~kg} \mathrm{Ca}$, and $2.5 \mathrm{~g} \mathrm{~B}$ per palm. The net amounts of nutrients required to meet similar production level of fruit bunches were $1.04 \mathrm{~kg} \mathrm{~N}, 0.16 \mathrm{~kg} \mathrm{P}, 1.85 \mathrm{~kg} \mathrm{~K}, 0.26 \mathrm{~kg} \mathrm{Mg}, 0.47 \mathrm{~kg} \mathrm{Ca}$, and $1.3 \mathrm{~g}$ B per palm per year if all nutrients contained in the pruned leaves were recycled. These results provide much-needed updated data on the dry-matter production and nutrient demand of tenera oil palm grown under current agronomic practices and also serve as a general yardstick for practitioners to further refine fertilizer recommendations.
\end{abstract}

Keywords: tenera; biomass; tree parts; nutrient concentration; nutrient partitioning

\section{Introduction}

Oil palm (Elaeis guineensis Jacq.) is the most productive edible oil-producing crop, with potential to produce up to $9.5 \mathrm{t}^{\text {oil ha }} \mathrm{h}^{-1}$ [1]. It requires a large amount of nutrients such as $\mathrm{N}, \mathrm{P}, \mathrm{K}, \mathrm{Mg}$, and $\mathrm{Ca}$ to maintain its high levels of standing biomass and drymatter production [2-6]. These nutrients are typically supplied by fertilizers, since oil palm is predominantly grown on highly weathered tropical soils with low soil-nutrient reserves $[7,8]$. Fertilizers are thus essential for sustaining growth of oil palm and economic production of fresh fruit bunches, which can account up to $32 \%$ of total production cost of 
fresh fruit bunches [9]. The high operating budget for fertilizers emphasizes the importance of more efficient use of fertilizers to maximize profitability of palm oil production while reducing potential detrimental effects of inorganic fertilizers on the environment [10].

The amount of nutrients required by a growing oil palm encompasses the amount of nutrients required to meet growth demand and deficiency demand [11], where deficiency demand is the amount of nutrients required to correct nutrient deficiency, which can be determined through measurements of nutrient concentrations in the leaflet and rachis tissues [12-14]. Meanwhile, growth demand is the amount of nutrients required to grow plant tissues such as spear leaves (unopened leaves), leaves, trunk, roots, and fresh fruit bunches, as well as to replace any plant tissues that are removed such as fresh fruit bunches, leaves and roots [11]. This growth demand for nutrients can be calculated from the amount of dry matter incorporated in the plant tissues and its nutrient concentrations.

A few studies have investigated the dry-matter production $[2,15,16]$ and nutrient content $[2,17]$ in oil palm through destructive measurement of oil palms of different ages. This had allowed determination of growth demand for nutrients and enabled formulation of the fertilizer requirement for oil palm. However, the oil palms sampled were mostly of the thick-shelled dura that has since been replaced by the thin-shelled tenera as the primary commercial oil-palm planting material [11] because of its higher oil-yield potential $\left(9.5 \mathrm{t}\right.$ il ha $\left.\mathrm{h}^{-1}\right)$ [1]. The higher oil-yield potential of tenera may be associated with greater total plant nutrient demand, and this nutrient demand is best determined through destructive measurements. However, this was not practiced until the work by Teoh and Chew [18] and Goh et al. [4,5] who studied the N, P, and K requirements of tenera. However, they restricted their measurements to mature palms aged between 12.5 and 19 years. More recently, a similar study was conducted on 14-year-old tenera but with limited measurements on the nutrient contents of fruit bunches, trunk tissue, and roots [6]. Other studies have been limited to determining the nutrient content of tenera bunches $[19,20]$. In one rare study, the micronutrient boron requirement of 20-82 month-old tenera was investigated [21]. Since then, there have been no such investigations carried out to determine the nutrient demand of tenera of different ages.

Therefore, it is obvious that the palm-oil industry lacks comprehensive knowledge on the nutrient demand of tenera at various stages of growth. Recent advances in oil-palm breeding and agronomic practices may have further influenced the uptake, partitioning, and accumulation of nutrients in tenera since the last comprehensive studies were conducted on tenera three decades ago $[4,5]$. As such, data collected from dura are sometimes used to fill this gap. This has raised concerns, since updated knowledge of nutrient requirements at various stages of tenera growth is essential for formulating fertilizer recommendations that meet agronomic, economic, and environmental objectives [22]. Goh et al. [21] found that 20-to-82-month-old tenera required about $27 \%$ more boron than dura of the same age. Tarmizi and Mohd Tayeb [6] found that $\mathrm{N}$ and $\mathrm{K}$ contents in tenera bunches were higher than those in dura bunches by $5 \%$ and $6 \%$, respectively, but the $\mathrm{P}$ and $\mathrm{Mg}$ contents were $16 \%$ lower than those in dura bunches. In another study, the N, P, K, and Mg contents in tenera bunches were 56, 54, 44, and $14 \%$ higher than those in dura bunches, respectively [19]. All these findings suggest that tenera, which has higher oil-yield potential, requires a larger amount of nutrients to sustain its productivity. As such, fertilizer recommendations based on older nutrient demand data might not adequately support the increased oil production. It is thus imperative that we reevaluate the nutrient uptake and partitioning patterns in tenera at different stages of growth.

We aimed to fill in this knowledge gap with the objective to quantify the standing biomass, dry-matter production, and nutrient demand of tenera of different ages, grown on inland sedentary soils under the current agronomic practices in Malaysia. 


\section{Materials and Methods}

\subsection{Study Site}

This study was carried out in an oil-palm plantation located in Layang-Layang $\left(1.81^{\circ} \mathrm{N}\right.$ $\left.103.45^{\circ} \mathrm{E}\right)$, Johor, Malaysia. The plantation has 129 oil-palm blocks with a total planted area of 2935 hectares. Block size varies from 5.1 to 34.8 hectares. There are 13 soil types found in the plantation but Harimau Series (Typic Paleudult), which is a deep, well-drained soil with $30 \%$ clay, 3\% silt, 34\% fine sand, and $29 \%$ coarse sand, dominates $56.5 \%$ of the total planted area [23]. The cation exchange capacity (CEC) of Hariamu Series is low at $4.09 \mathrm{cmol} \mathrm{kg}^{-1}$, with exchangeable $\mathrm{K}, \mathrm{Ca}$, and $\mathrm{Mg}$ at $0.11,0.68$ and $0.18 \mathrm{cmol} \mathrm{kg}^{-1}$, respectively. Harimau Series soil is moderately acidic, with a $\mathrm{pH}$ of $4.5,0.13 \%$ total $\mathrm{N}$, and $8.2 \mathrm{ppm}$ available $\mathrm{P}$. The topography of the study site is undulating, with slopes ranging from 2 to $6^{\circ}$. Annual rainfall received from 2011 to 2019 averaged ( \pm sd) at $2522 \pm 66 \mathrm{~mm}$, with $135 \pm 3$ rain days. Mean annual air temperature averaged at $26.5 \pm 0.5^{\circ} \mathrm{C}$. The study site is thus deemed favorable for growing oil palm $[8,24]$.

\subsection{Planting Materials}

Tenera (Deli Dura $\times$ AVROS Pisifera) palms were sampled. These were fertilized commercial palms grown under the current Sime Darby Plantation agromanagement practices. These palms were sampled from different blocks, where each block is planted with one specific palm age. Most blocks were initially planted with 148 palms per hectare but there are some blocks planted with higher densities of 160-180 palms per hectare. Based on the developed soil map by the Sime Darby Plantation, palms planted in blocks with similar terrains and with Harimau Series as dominant soil type were selected for sampling. The age of palms at time of sampling were 12, 29, 48, 88, 133, 209, and 238 months old, calculated from the time of nursery planting. Four palms from each age group were randomly sampled. Stunted, abnormal, and roadside palms were excluded from sampling. The 88-month-old palms sampled from a high-density planting block were healthy and not etiolated at the time of sampling. Fertilizers were applied on an annual basis and the last three years' fertilizer quantities applied to the sampled palms prior to destructive sampling were averaged and are provided in Table 1 . The nursery palms (12 months old) only received one year of fertilizer applications while the 29-month-old palms received one year of fertilizer applications after field planting. Oil palm is normally raised in the nursery for 12 months before transplanting in the field.

Table 1. Average fertilizer rates applied to the sampled tenera palms prior to destructive sampling SPH and n.a. denote actual stands per hectare at time of sampling, and not applicable, respectively.

\begin{tabular}{cccccccc}
\hline \multirow{2}{*}{$\begin{array}{c}\text { Palm Age } \\
\text { (Months) }\end{array}$} & SPH & \multicolumn{6}{c}{ Quantity of Nutrients Applied (kg palm ${ }^{-1}$ year $^{-1}$ ) } \\
\cline { 3 - 8 } & & N & P & K & Mg & Ca & B \\
\hline 12 & n.a. & 0.04 & 0.02 & 0.02 & 0.01 & 0 & 0 \\
29 & 157 & 0.60 & 0.51 & 0.71 & 0.06 & 0.57 & 0 \\
48 & 148 & 0.66 & 0.40 & 1.06 & 0.12 & 0.52 & 0.009 \\
88 & 173 & 0.97 & 0.21 & 1.93 & 0.28 & 0.52 & 0.009 \\
133 & 150 & 0.89 & 0.24 & 1.91 & 0.26 & 0.72 & 0.009 \\
209 & 133 & 0.89 & 0.22 & 1.99 & 0.26 & 0.70 & 0.009 \\
238 & 134 & 0.85 & 0.21 & 1.85 & 0.23 & 0.63 & 0.009 \\
\hline
\end{tabular}

\subsection{Destructive Sampling}

The tenera palms selected for destructive sampling were harvested, uprooted, and separated into different morphological components viz. leaves (further divided into leaflets, rachis, and petiole), leaf bases, spear leaves, cabbage, trunk, bole, roots, male and female inflorescences, and bunches [2,18]. Figure 1 briefly illustrates the sampling of various parts of the oil palm. Root biomass may contain significant amounts of nutrients, but no measurement was made in this study. 


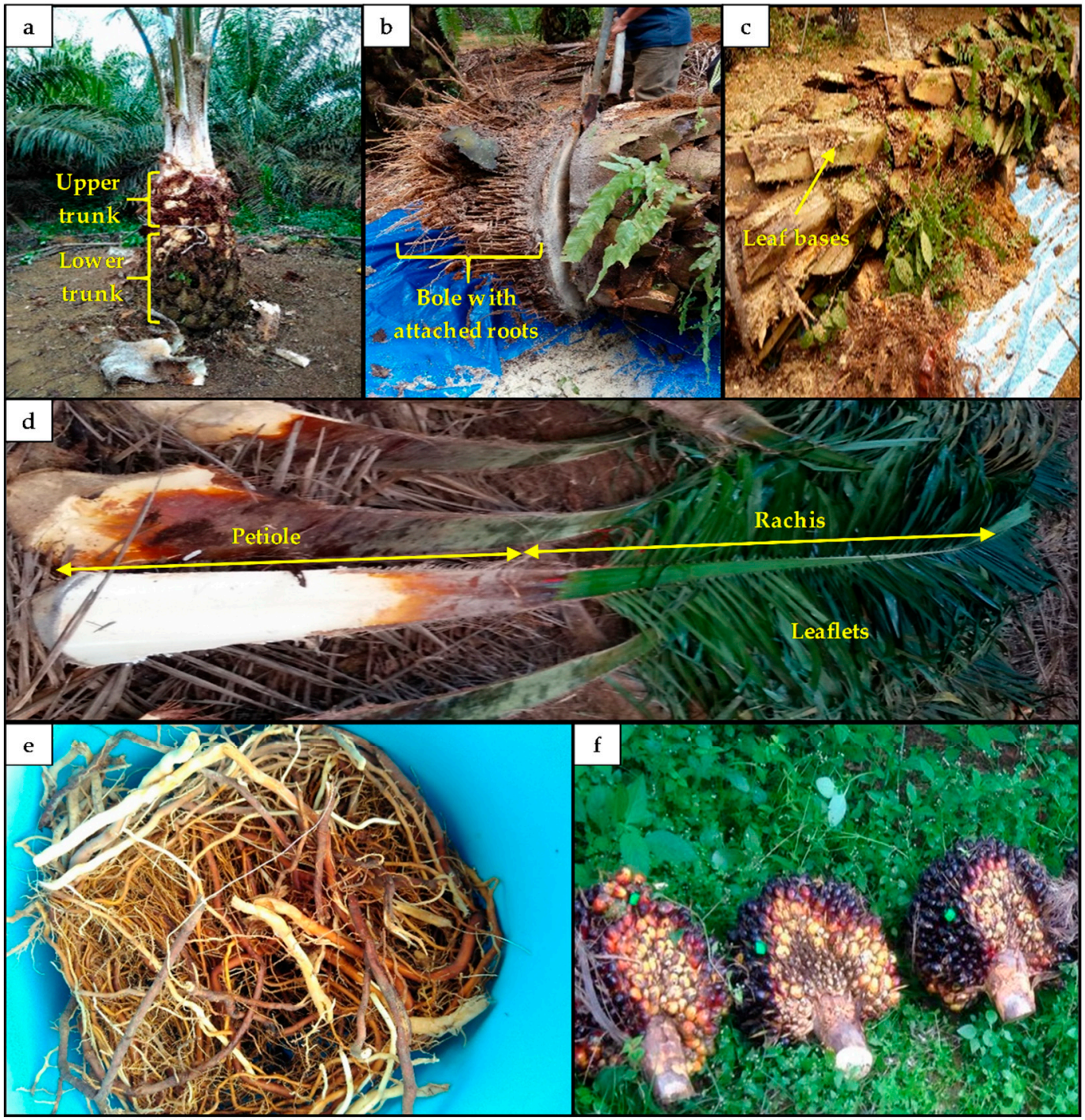

Figure 1. Destructive sampling of the tenera oil palm. (a) A 5-year-old palm, after almost all leaves were removed before it was felled. Upper and lower trunk were identified and marked. (b) Cutting the bole of an uprooted palm using chainsaw and chisel. (c) Oil-palm trunk with leaf bases attached to it. (d) Oil-palm leaves with petiole, rachis, and pinnae identified. (e) Cleaned oil palm roots. (f) Harvested bunches. Left-ripe bunch; middle and right-unripe bunches.

\subsubsection{Leaves}

Each leaf was removed individually and divided into leaflets, rachis, and petiole. Leaflets were sampled systematically by sampling one leaflet for every ten leaflets until the tip of the rachis for both sides of a leaf. These leaflets were then bulked, weighed, and treated separately for nutrient analysis. All remainder leaflets were cut off, bulked, weighed, and dried. Each of the rachis and petiole was cut into six and four equal parts respectively, bulked and weighed. A 10-cm long subsample was cut from the middle of each part, bulked, weighed, dried and used for nutrient analysis. 'Spear leaves' (unopened leaves) were cut off from the crown after felling the sampled palm, numbered and cut into six parts of equal length, bulked and weighed. A $10 \mathrm{~cm}$ long subsample was cut from the middle of each part, bulked, weighed, dried and used for nutrient analysis.

\subsubsection{Trunk}

After the removal of all leaves, the whole trunk was uprooted with the bole. The bole was separated from the trunk, then the trunk was further separated into upper and 
lower trunk parts, because the tissues of both trunk sections contain contrasting nutrient concentrations [2]. The upper trunk, which supports the leaves, is defined as the section from the base of Leaf- 41 to the base of Leaf-1 (Figure 1a). The upper trunk was cut into three equal sections, and each section was weighed separately. A 15-cm thick subsection was cut from the middle of each trunk section and weighed. Each trunk subsection was further cut into eight equal parts, and two one-eighth parts were taken randomly. These subsamples were bulked separately, weighed, and used for nutrient analysis. The lower trunk, which forms the major portion of palm trunk is defined as the section between the base of Leaf-41 and the trunk base where the bole was separated (Figure 1b). The lower trunk was then cut into three equal sections and treated in the same way as the upper trunk.

\subsubsection{Cabbage}

The cabbage is the succulent tissue found at the apex of the upper trunk, which is basically comprised of a soft mass of immature leaves and inflorescences that contain much higher concentrations of nutrients. It was treated separately. The cabbage was cut out, chopped, dried, weighed, and taken for nutrient analysis.

\subsubsection{Bole}

The bole was separated from the trunk, and soils attached to the bole and the roots were removed by spraying with water. Roots attached to the bole were removed with a sharp knife. The bole was weighed and then cut into eight longitudinal sections of approximate size. Two one-eighth sections were weighed and taken for nutrient analysis. All roots removed from the bole were bulked and weighed, and about $2 \mathrm{~kg}$ of each of the roots was taken for nutrient analysis.

\subsubsection{Leaf Bases}

All leaf bases attached to each section of upper and lower trunk were removed, bulked, and weighed. Two pieces of leaf bases from each section were randomly sampled, weighed and used for nutrient analysis.

\subsubsection{Fresh Fruit Bunches}

All fruit bunches were harvested before palm felling and were separated into ripe and unripe bunches. Each bunch was weighed in the field and immediately taken to the laboratory where each bunch was treated separately [6]. In the laboratory, every bunch was stripped and separated into fruits, stalks, and spikelets with trash and weighed. All of the fruits were cleaned and separated, firstly into pericarp and nut, and were again weighed individually. The stalk, spikelet, and pericarp were diced. A maximum of $2 \mathrm{~kg}$ of subsamples from stalk, spikelet, and pericarp component were dried overnight at $70^{\circ} \mathrm{C}$ before grinding in a mill. The nut was dried similarly and then cracked with a hammer to extract the kernel. After separation, the shell was placed in a canvas bag and crushed with a hammer before grinding in a mill. The kernel was pounded up in a porcelain mortar. The ground material was then quartered for a subsample of about $250 \mathrm{~g}$. The stalk was cleaned and treated in the same way as the spikelet/trash.

\subsection{Laboratory Analysis}

All palm organs were wiped clean with distilled water before they were cut into smaller pieces and dried to a constant weight between 50 to $70{ }^{\circ} \mathrm{C}$ using a Memmert laboratory oven Model UF450 (Memmert GmbH, Schwabach, Germany). Total N in the organ samples was determined using the combustion method with an elemental analyzer with temperature set at $900{ }^{\circ} \mathrm{C}$ [25]; P was determined colorimetrically by the yellow phosphovanadate complex using the AutoAnalyzer after dry-ashing [26]; K, Mg, and Ca by the Atomic Absorption Spectrophotometer after dry-ashing [27]; and B by the Azomethine method using a UV Spectrophotometer after dry-ashing with $\mathrm{H}_{2} \mathrm{SO}_{4}$ [28]. 


\subsection{Data Analysis}

\subsubsection{Determination of Dry Weight}

Total dry weight of a specific palm tissue, $\mathrm{DW}_{\mathrm{x}}$ (where $\mathrm{x}$ represents a specific tree part, such as spear leaves, leaflets, rachis, petiole, leaf bases, cabbage, trunk, or bole) for each palm age was determined as:

$$
\mathrm{DW}_{\mathrm{x}}=\mathrm{W}_{0} \times \frac{\mathrm{W}_{2}}{\mathrm{~W}_{1}}
$$

where $W_{0}$ is the total fresh weight of a specific palm tissue, and $W_{1}$ and $W_{2}$ is the subsample fresh weight and dry weight of a specific palm tissue, respectively. All weights are in $\mathrm{kg} \mathrm{palm}^{-1}$.

\subsubsection{Estimation of Dry-Matter Production}

Dry weights determined for each replicate of spear leaves, trunk, and bole at months 12 , $29,48,88,133,209$, and 238 were treated individually and subjected to nonlinear regression analysis using TableCurve 2D version 5.1 (SYSTAT Software Inc., San Jose, CA, USA, 2002) to estimate annual dry matter incorporated in spear leaves $\left(\mathrm{DM}_{\text {spear }}\right)$, trunk $\left(\mathrm{DM}_{\text {trunk }}\right)$, and bole $\left(\mathrm{DM}_{\text {bole }}\right)$. Models generated from the curve-fitting software were examined. Parsimonious models with low fitting standard error and high $\mathrm{R}^{2}$ were selected [29]. From the fitted curves, monthly $\mathrm{DM}_{\text {spear }}, \mathrm{DM}_{\text {trunk }}$, and $\mathrm{DM}_{\text {bole }}$ were then calculated and summed to give annual dry-matter production in $\mathrm{kg} \mathrm{palm}^{-1}$ year $^{-1}$. Trunk dry matter includes the cabbage and the upper and lower trunk. Annual leaf dry-matter production $\left(\mathrm{DM}_{\text {leaf }}\right.$; $\mathrm{kg} \mathrm{palm}^{-1}$ year $^{-1}$ ) was calculated following Corley et al. [16] as:

$$
\mathrm{DM}_{\text {leaf }}=\left(\frac{\mathrm{DW}_{\text {leaf }}}{\mathrm{FN}}\right) \times \mathrm{FPR}
$$

where $\mathrm{DW}_{\text {leaf }}$ is the total dry weight of leaves $\left(\mathrm{kg} \mathrm{palm}^{-1}\right)$ at the time of sampling, FN is the total number of leaves per palm at the time of sampling, and FPR is the 12-month period's total leaf numbers produced for the year preceding the destructive sampling (no. palm ${ }^{-1}$ year $^{-1}$ ). The number of leaves produced by the sampled palms was estimated from Equation (3), which was derived from three oil-palm planting-density trials carried out under the Malaysian inland environment (see Supplementary Figure S1), which is similar to the environment of this study [30]. The number of leaves produced in a month for a given palm age was estimated as:

$$
\mathrm{FPR}_{\text {month }}=2.9645 \exp (- \text { age } / 380.6418)
$$

where age is the palm age in months since nursery planting. Annual root dry-matter production $\left(\mathrm{DM}_{\text {root }} ; \mathrm{kg} \mathrm{palm}^{-1}\right.$ year $\left.^{-1}\right)$ was derived from the aboveground vegetative dry-matter production (VDM) estimated in this study as:

$$
\mathrm{DM}_{\text {root }}=\mathrm{VDM} \times 0.104
$$

where 0.104 is the mean root-to-shoot ratio, calculated from Henson and Chai [31]. The dry weight of fresh fruit bunches $\left(\mathrm{DM}_{\mathrm{FFB}}\right)$ in $\mathrm{kg}_{\mathrm{palm}}{ }^{-1}$ year $^{-1}$ for the year preceding destructive sampling was calculated as:

$$
\mathrm{DM}_{\mathrm{FFB}}=\left(\frac{\mathrm{Y}_{\mathrm{FFB}}}{\mathrm{SPH}}\right) \times 0.5275
$$

where $Y_{F F B}$ is the 12-month period's total weight of fresh fruit bunches $\left(\mathrm{kg} \mathrm{ha}^{-1} \mathrm{year}^{-1}\right)$, $\mathrm{SPH}$ is the number of palms per hectare for the block from which the sampled palms were taken, and 0.5275 is a constant used for converting the weight of fresh fruit bunches to the dry weight [32]. 


\subsubsection{Estimation of Nutrient Demand}

The annual quantity of nutrient required to grow and maintain each palm organ $\left(\mathrm{N}_{x}\right.$; $\mathrm{kg} \mathrm{palm}^{-1}$ year $^{-1}$ ) for each palm age was calculated as:

$$
\mathrm{N}_{x}=\mathrm{DM}_{x} \times \mathrm{C}_{x}
$$

where $\mathrm{DM}_{x}$ is the amount of dry matter incorporated in a specific palm organ over a year, and where $x$ represents bunches, spear leaves, leaves, trunk, bole, or roots. $\mathrm{C}_{x}$ (\% dry matter) is the concentration of a nutrient element for a specific palm organ, $x$. The annual nutrient demand calculated for each vegetative organ was summed to give the annual nutrient demand for vegetative growth. The sum of nutrient demand for vegetative growth and bunch production gives the total nutrient demand.

\subsubsection{Statistical Analysis}

Dry weight and dry-matter production data, and nutrient concentrations data collected from vegetative tissues and components of fruit bunches were analyzed using JMP ${ }^{\circledR}$ Version 14 (SAS Institute Inc., Cary, NC, USA, 2021). The growth stages of tenera were divided into nursery (12 months old), immature (29-48 months old), and mature (88-238 months old). Means were separated by the Tukey HSD test procedure at the threshold significant level of $5 \%$. Pearson correlations between tissues' nutrient concentrations with palm age in 12-to-238-month-old tenera were analyzed using JMP ${ }^{\circledR}$ Version 14 (SAS Institute Inc., Cary, NC, USA, 2021).

\section{Results}

\subsection{Vegetative Biomass and Its Distribution}

Total vegetative biomass increased almost linearly from $1.3 \mathrm{~kg} \mathrm{palm}^{-1}$ at 12 months old to $808.6 \mathrm{~kg} \mathrm{palm}^{-1}$ at 238 months old (Table 2). Trunk biomass alone increased from $1.1 \mathrm{~kg} \mathrm{palm}^{-1}$ at 29 months after planting to $430.8 \mathrm{~kg}$ palm ${ }^{-1}$ at 238 months old, while leaf biomass, which is comprised of leaflets, rachis, and petiole increased from $1.0 \mathrm{~kg} \mathrm{palm}^{-1}$ at 12 months after planting to $223.3 \mathrm{~kg} \mathrm{palm}^{-1}$ after 133 months, with little increase thereafter. The biomass of leaf bases increased substantially from $11.4 \mathrm{~kg}^{-1}$ palm ${ }^{-1}$ at 48 months old to $105.7 \mathrm{~kg} \mathrm{palm}^{-1}$ at 133 months old before declining to 90.4 and $59.6 \mathrm{~kg} \mathrm{palm}^{-1}$ at 209 and 238 months old, respectively. The bole was taken as the only belowground vegetative biomass in this study, while roots attached to the bole were excluded. Bole biomass increased from $0.24 \mathrm{~kg} \mathrm{palm}^{-1}$ at 12 months old to $58.7 \mathrm{~kg}$ palm ${ }^{-1}$ after 238 months of planting.

Table 2. Dry weights (mean \pm SE) of standing vegetative biomass of tenera oil palm sampled in Malaysia.

\begin{tabular}{|c|c|c|c|c|c|c|c|c|c|}
\hline \multirow{2}{*}{$\begin{array}{l}\text { Palm } \\
\text { Age * }\end{array}$} & \multicolumn{9}{|c|}{ Vegetative Biomass (kg palm $\left.{ }^{-1}\right)$} \\
\hline & Leaflets & Rachis & Petiole & Leaves & Spear Leaves & $\ddagger$ Trunk & Leaf Bases & Bole & Total \\
\hline 12 & $0.37 \pm 0.05 \mathrm{e}$ & $0.24 \pm 0.03 c$ & $0.4 \pm 0.1 c$ & $1.0 \pm 0.1 \mathrm{~d}$ & $0.045 \pm 0.005 \mathrm{~d}$ & - & - & $0.24 \pm 0.01 \mathrm{c}$ & $1.3 \pm 0.1 \mathrm{f}$ \\
\hline 29 & $3.2 \pm 0.1 \mathrm{e}$ & $2.0 \pm 0.1 c$ & $5.1 \pm 0.5 c$ & $10.2 \pm 0.7 \mathrm{~d}$ & $0.35 \pm 0.04 \mathrm{~d}$ & $1.1 \pm 0.1 \mathrm{e}$ & - & $0.57 \pm 0.02 c$ & $12.3 \pm 0.7 \mathrm{f}$ \\
\hline 48 & $26.8 \pm 0.2 \mathrm{~d}$ & $21.1 \pm 0.8 c$ & $38.6 \pm 1.9 \mathrm{~b}$ & $87.6 \pm 0.7 c$ & $3.2 \pm 0.1 \mathrm{~cd}$ & $30.1 \pm 0.2 \mathrm{de}$ & $11.4 \pm 0.3 c$ & $2.0 \pm 0.04 c$ & $134.0 \pm 0.6 \mathrm{e}$ \\
\hline 88 & $49.4 \pm 3.3 c$ & $49.6 \pm 5.6 b$ & $54.0 \pm 6.2 b$ & $153.0 \pm 14.8 \mathrm{~b}$ & $6.0 \pm 1.0 \mathrm{bcd}$ & $85.1 \pm 4.8 \mathrm{~d}$ & $72.7 \pm 3.1 \mathrm{~b}$ & $10.1 \pm 1.1 \mathrm{bc}$ & $326.9 \pm 16.9 \mathrm{~d}$ \\
\hline 133 & $61.9 \pm 2.3 b$ & $75.5 \pm 11.9 \mathrm{a}$ & $86.0 \pm 8.9 \mathrm{a}$ & $223.3 \pm 22.5 \mathrm{a}$ & $11.3 \pm 1.5 \mathrm{ab}$ & $216.8 \pm 7.7 c$ & $105.7 \pm 11.1 \mathrm{a}$ & $20.7 \pm 2.5 b$ & $577.9 \pm 29.3 c$ \\
\hline 209 & $72.7 \pm 1.4 \mathrm{a}$ & $70.8 \pm 1.5 \mathrm{ab}$ & $92.1 \pm 4.7 \mathrm{a}$ & $235.5 \pm 6.6 \mathrm{a}$ & $8.8 \pm 0.6 \mathrm{abc}$ & $308.9 \pm 3.0 \mathrm{~b}$ & $90.4 \pm 2.0 \mathrm{ab}$ & $21.1 \pm 1.2 b$ & $664.7 \pm 7.5 b$ \\
\hline 238 & $68.8 \pm 3.5 \mathrm{ab}$ & $90.2 \pm 6.4 \mathrm{a}$ & $87.3 \pm 7.4 \mathrm{a}$ & $246.2 \pm 12.4 \mathrm{a}$ & $13.3 \pm 2.9 \mathrm{a}$ & $430.8 \pm 34.3 \mathrm{a}$ & $59.6 \pm 11.1 b$ & $58.7 \pm 7.0 \mathrm{a}$ & $808.6 \pm 34.3 \mathrm{a}$ \\
\hline
\end{tabular}

* Months since nursery planting. ${ }^{\ddagger}$ Trunk comprises cabbage and upper and lower trunk. Means sharing the same letter within each parameter are not significantly different at $p \leq 0.05$.

Leaves and trunk make up the bulk of vegetative biomass measured in this study, while spear leaves and bole contributed between $1-7 \%$ and $1-18 \%$ to total vegetative biomass, respectively (Figure 2). The proportion of accumulated biomass in leaves decreased with age, as the proportion of biomass in trunk increased. The contribution of leaf bases to total vegetative biomass appears substantial, especially from 88 to 209 months after planting. Within the leaf biomass, leaflets and rachis contributed $30 \%$ each, while the petiole took up the remaining $40 \%$. 


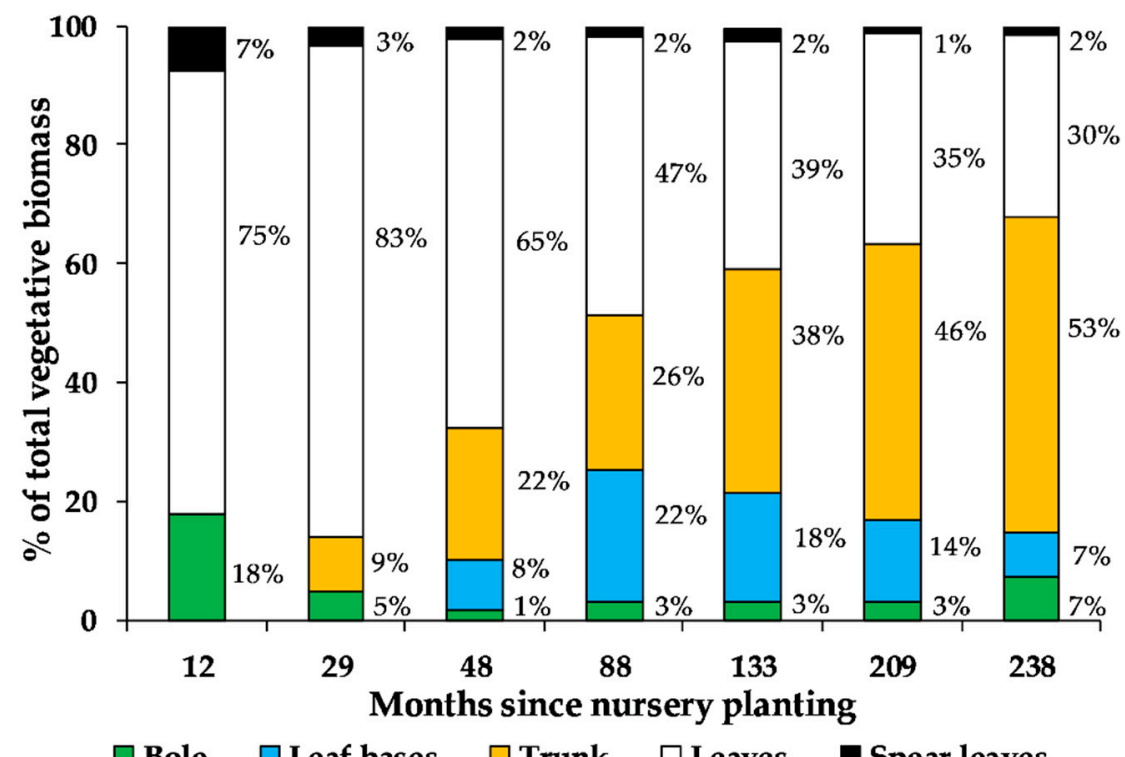

Figure 2. Proportion of vegetative biomass of different ages of tenera oil palm.

\subsection{Estimation of Dry-Matter Production}

Cumulative dry matter incorporated in tree parts was estimated through nonlinear regression (Table 3). The cumulative dry weights for spear leaves, trunk, and bole fitted well to modified exponential models. This method was highly satisfactory and gave accurate estimate of dry-matter production as $\mathrm{R}^{2}$ of all the equations determined for most of the replicates exceeded 0.90 . Lower $\mathrm{R}^{2}$ found in replicate 4 of $\mathrm{DW}_{\text {spear }}$ and all replicates of $\mathrm{DW}_{\text {bole }}$ was caused by outliers.

Table 3. Equations to calculate the cumulative dry matter incorporated in spear leaves, trunk, and bole of tenera oil palm. The variable 'age' is the number of months since nursery planting and $\mathrm{DW}_{\text {spear }}, \mathrm{DW}_{\text {trunk}}$, and $\mathrm{DW}_{\text {bole }}$ are dry weights $\left(\mathrm{kg} \mathrm{palm}^{-1}\right)$ accumulated in spear leaves, trunk, and bole, respectively, at the time of sampling.

\begin{tabular}{|c|c|c|c|c|c|c|}
\hline Equation & Replicate & $a$ & $b$ & SE of Fits & $\mathbf{R}^{2}$ & $p$-Value \\
\hline \multirow{4}{*}{$\mathrm{DW}_{\text {spear }}=\exp \left(\mathrm{a}-\frac{\mathrm{b}}{\text { age }^{1.5}}\right)$} & 1 & 2.2826 & -417.6429 & 0.66 & 0.97 & $<0.01$ \\
\hline & 2 & 2.4968 & -497.2144 & 1.01 & 0.95 & $<0.01$ \\
\hline & 3 & 2.6945 & -439.7475 & 2.90 & 0.78 & $<0.01$ \\
\hline & 4 & 3.1698 & -825.2037 & 4.67 & 0.69 & $<0.05$ \\
\hline \multirow{4}{*}{$\mathrm{DW}_{\text {trunk }}=\exp \left(\mathrm{a}-\frac{\mathrm{b}}{\mathrm{age}^{0.5}}\right)$} & 1 & 8.2456 & -33.6274 & 35.74 & 0.96 & $<0.01$ \\
\hline & 2 & 7.9697 & -31.4995 & 15.71 & 0.99 & $<0.01$ \\
\hline & 3 & 8.9256 & -42.5053 & 49.53 & 0.94 & $<0.01$ \\
\hline & 4 & 7.6207 & -26.7059 & 21.30 & 0.98 & $<0.01$ \\
\hline \multirow{4}{*}{$\mathrm{DW}_{\text {bole }}=\exp \left(\mathrm{a}-\frac{\mathrm{b}}{\mathrm{age}^{0.5}}\right)$} & 1 & 8.5704 & -67.0073 & 13.85 & 0.76 & $<0.01$ \\
\hline & 2 & 5.4891 & -28.7558 & 7.30 & 0.80 & $<0.01$ \\
\hline & 3 & 6.3014 & -36.5681 & 9.58 & 0.80 & $<0.01$ \\
\hline & 4 & 7.0320 & -45.4535 & 11.97 & 0.77 & $<0.01$ \\
\hline
\end{tabular}

\subsection{Dry-Matter Production}

Whole-palm dry-matter production increased with palm age but at a decreasing rate (Table 4). This was mainly attributed to the increasing amount of dry matter incorporated in vegetative tissue and fruit bunches during the first 133 months of growth. However, as the amount of dry matter incorporated in leaves, trunk, roots, and fruit bunches started to stabilize at about 133 months onwards, the rate of whole-palm dry-matter production 
decreased. The amounts of dry matter used for the spear leaves and bole were very small, averaging at 0.6 and $2.3 \mathrm{~kg} \mathrm{palm}^{-1}$ year $^{-1}$, respectively.

Table 4. Dry matter (mean $\pm \mathrm{SE}$ ) incorporated in vegetative tissues $\left(\mathrm{kg} \mathrm{palm}^{-1}\right.$ year $\left.^{-1}\right)$ and fruit bunches of tenera oil palm. No SE values were calculated for fruit bunches, since the weight of fruit bunches was obtained from the actual bunch weight recorded in a single block.

\begin{tabular}{|c|c|c|c|c|c|c|c|c|}
\hline $\begin{array}{l}\text { Palm } \\
\text { Age * }\end{array}$ & $\begin{array}{c}\text { Spear } \\
\text { Leaves }\end{array}$ & Leaves & $\ddagger$ Trunk & Bole & Roots & $\begin{array}{c}\text { Total } \\
\text { Vegetative }\end{array}$ & $\begin{array}{c}\text { Fruit } \\
\text { Bunches }\end{array}$ & Whole Palm \\
\hline 12 & $0.045 \pm 0.005 c$ & $1.0 \pm 0.1 \mathrm{c}$ & - & $0.24 \pm 0.01 \mathrm{~d}$ & $0.17 \pm 0.01 c$ & $1.5 \pm 0.2 c$ & - & $1.5 \pm 0.2 \mathrm{~d}$ \\
\hline 29 & $0.5 \pm 0.2 \mathrm{bc}$ & $10.6 \pm 0.4 c$ & $6.7 \pm 1.8 \mathrm{~b}$ & $0.4 \pm 0.2 \mathrm{~cd}$ & $2.7 \pm 0.1 c$ & $21.1 \pm 1.4 \mathrm{c}$ & - & $21.1 \pm 1.4 \mathrm{~d}$ \\
\hline 48 & $1.6 \pm 0.1 \mathrm{a}$ & $50.7 \pm 0.4 \mathrm{~b}$ & $15.1 \pm 1.9 \mathrm{ab}$ & $1.2 \pm 0.3 \mathrm{bcd}$ & $7.9 \pm 0.1 b$ & $76.5 \pm 1.6 c$ & 36.0 & $112.5 \pm 1.6 \mathrm{c}$ \\
\hline 88 & $1.1 \pm 0.3 \mathrm{ab}$ & $112.0 \pm 12.1 \mathrm{a}$ & $23.6 \pm 0.6 \mathrm{a}$ & $2.4 \pm 0.2 \mathrm{abcd}$ & $14.4 \pm 1.3 \mathrm{a}$ & $153.7 \pm 13.3 \mathrm{a}$ & 77.9 & $231.6 \pm 13.3 b$ \\
\hline 133 & $1.1 \pm 0.2 b c$ & $138.4 \pm 15.7 \mathrm{a}$ & $25.7 \pm 2.1 \mathrm{a}$ & $3.3 \pm 0.4 \mathrm{abc}$ & $17.0 \pm 1.9 \mathrm{a}$ & $184.9 \pm 18.6 \mathrm{a}$ & 100.6 & $285.5 \pm 18.6 \mathrm{a}$ \\
\hline 209 & $0.2 \pm 0.1 c$ & $122.1 \pm 4.3 \mathrm{a}$ & $24.2 \pm 3.5 \mathrm{a}$ & $4.0 \pm 1.0 \mathrm{ab}$ & $15.1 \pm 0.5 \mathrm{a}$ & $165.7 \pm 4.3 \mathrm{a}$ & 121.1 & $286.8 \pm 4.3 \mathrm{a}$ \\
\hline 238 & $0.2 \pm 0.1 \mathrm{c}$ & $127.5 \pm 4.2 \mathrm{a}$ & $23.2 \pm 3.7 \mathrm{a}$ & $4.2 \pm 1.2 \mathrm{a}$ & $13.3 \pm 0.4 \mathrm{a}$ & $168.3 \pm 5.9 \mathrm{a}$ & 95.8 & $264.1 \pm 5.9 \mathrm{ab}$ \\
\hline
\end{tabular}

* Months since nursery planting. ${ }^{\ddagger}$ Trunk comprises cabbage and upper and lower trunk. Means sharing the same letter within each parameter are not significantly different at $p \leq 0.05$.

\subsection{Nutrients in Vegetative Tissues}

The concentrations of $\mathrm{N}, \mathrm{P}, \mathrm{K}, \mathrm{Mg}, \mathrm{Ca}$, and $\mathrm{B}$ in the vegetative tissues of nursery, immature and mature tenera palms are summarized in Table 5, while concentrations of these nutrients in vegetative tissues for each palm age are provided in Tables S1 and S2. In general, the concentrations of $\mathrm{N}, \mathrm{P}, \mathrm{K}, \mathrm{Mg}, \mathrm{Ca}$, and $\mathrm{B}$ in vegetative tissues varied depending on type of tissues, palm age, and nutrient elements. Nutrient concentrations between palms varied considerably depending on palm age, nutrient element, and tissue types. For a whole palm, the coefficient of variation for $\mathrm{N}, \mathrm{P}, \mathrm{K}, \mathrm{Mg}, \mathrm{Ca}$, and $\mathrm{B}$ concentrations could vary between 5.7 and $20.7 \%, 9.1$ and $27.3 \%, 8.2$ and $33.5 \%, 5.0$ and $16.1 \%, 2.9$ and $20.9 \%$, and 2.8 and $19.2 \%$, respectively.

Among the vegetative tissues, the cabbage, which comprises mainly meristemic cells, had the highest concentrations of $\mathrm{N}, \mathrm{P}, \mathrm{K}, \mathrm{Mg}, \mathrm{Ca}$, and $\mathrm{B}$, while roots in general had the lowest concentrations of these nutrients. The leaflets, which serve as photosynthetic organ had the second highest $\mathrm{N}$ concentration. The trunk, which is a storage organ, had higher concentrations of $\mathrm{N}, \mathrm{P}, \mathrm{K}, \mathrm{Mg}$, and $\mathrm{Ca}$ after the cabbage and leaflets, except for $\mathrm{Mg}$ concentration in the trunk of mature palms. Leaf bases, which are parts of the petiole that are attached to the trunk, had comparable concentrations of $\mathrm{N}, \mathrm{P}, \mathrm{K}, \mathrm{Mg}$, and $\mathrm{Ca}$ to the petiole.

Averaged over the whole palm, the concentrations of $\mathrm{N}$ and $\mathrm{Mg}$ of 12-month-old nursery tenera were lower than in tenera of the same age studied previously (Table 6), but $\mathrm{P}$ concentration was comparable, and $\mathrm{K}$ and $\mathrm{Ca}$ concentrations were higher. For the whole immature tenera, the concentrations of $\mathrm{N}$ and $\mathrm{Mg}$ were comparable to tenera studied by $\mathrm{Ng}$ et al. [2] but $\mathrm{P}, \mathrm{K}$, and $\mathrm{Ca}$ concentrations were higher (Table 6). The concentrations of $\mathrm{N}$, $\mathrm{P}, \mathrm{K}$, and $\mathrm{Ca}$ of mature tenera studied here were higher than previously studied dura and tenera except for $\mathrm{Mg}$ in mature dura (Table 6).

$\mathrm{K}$ concentration in the leaves, trunk, and the whole palm did not change with palm age while concentrations of $\mathrm{N}, \mathrm{P}$, and $\mathrm{Mg}$ decreased with age (Table 7). On the other hand, $\mathrm{Ca}$ and $\mathrm{B}$ concentrations decreased with age in the trunk and the whole palm but not in the leaves.

\subsection{Nutrients in Fresh Fruit Bunches}

The nutrient concentrations in fresh fruit bunches and their components are given in Table 8. For the whole bunch, the order of nutrient concentrations is: $\mathrm{K}(1.20 \%)>\mathrm{N}(0.90 \%)>$ $\mathrm{Ca}(0.44 \%)>\mathrm{Mg}(0.25 \%)>\mathrm{P}(0.150 \%)>\mathrm{B}\left(11.1 \mathrm{mg} \mathrm{kg}^{-1}\right)$. Among the bunch components, the kernel had the highest $\mathrm{N}$ and $\mathrm{P}$ concentrations, while the stalk had the highest $\mathrm{K}$ and $\mathrm{B}$ concentrations. The mesocarp, on the other hand, had the highest $\mathrm{Mg}$ and $\mathrm{Ca}$ concentrations. It is also apparent that the tenera bunches studied here are much richer in nutrients than the dura bunches, as well as other previously studied tenera bunches (Table 9). 
Table 5. Concentrations (mean $\pm \mathrm{SE}$ ) of $\mathrm{N}, \mathrm{P}, \mathrm{K}, \mathrm{Mg}, \mathrm{Ca}$, and $\mathrm{B}$ in vegetative tissues of nursery, immature, and mature tenera oil palms.

\begin{tabular}{|c|c|c|c|c|c|c|}
\hline \multirow{2}{*}{$\begin{array}{l}\text { Plant } \\
\text { Tissue }\end{array}$} & \multicolumn{5}{|c|}{$\%$ of Dry Matter } & \multirow{2}{*}{$\frac{\mathrm{mg} \mathrm{kg}^{-1}}{\text { B }}$} \\
\hline & $\mathbf{N}$ & $\mathbf{P}$ & $\mathbf{K}$ & $\mathrm{Mg}$ & $\mathrm{Ca}$ & \\
\hline & \multicolumn{6}{|c|}{ Nursery seedlings (12 months old) } \\
\hline Spear leaves & $1.86 \pm 0.20 \mathrm{ab}$ & $0.312 \pm 0.021 \mathrm{a}$ & $2.38 \pm 0.10 \mathrm{a}$ & $0.28 \pm 0.02 \mathrm{a}$ & $0.39 \pm 0.04 \mathrm{ab}$ & $11.6 \pm 0.3 \mathrm{abc}$ \\
\hline Leaflets & $2.60 \pm 0.10 \mathrm{a}$ & $0.186 \pm 0.003 \mathrm{bc}$ & $1.95 \pm 0.07 b$ & $0.27 \pm 0.04 \mathrm{a}$ & $0.49 \pm 0.03 \mathrm{a}$ & $13.0 \pm 0.4 \mathrm{ab}$ \\
\hline Rachis & $0.53 \pm 0.05 c$ & $0.106 \pm 0.015 \mathrm{~d}$ & $1.90 \pm 0.06 \mathrm{~b}$ & $0.09 \pm 0.01 \mathrm{~b}$ & $0.24 \pm 0.04 \mathrm{bc}$ & $6.4 \pm 0.4 \mathrm{~d}$ \\
\hline Petiole & $0.55 \pm 0.10 c$ & $0.119 \pm 0.012 \mathrm{~cd}$ & $1.50 \pm 0.11 c$ & $0.14 \pm 0.01 b$ & $0.20 \pm 0.02 c$ & $8.3 \pm 0.3 \mathrm{~cd}$ \\
\hline Bole & $1.28 \pm 0.29 \mathrm{bc}$ & $0.224 \pm 0.023 \mathrm{~b}$ & $1.39 \pm 0.08 c$ & $0.16 \pm 0.01 b$ & $0.18 \pm 0.05 c$ & $8.8 \pm 0.3 \mathrm{~cd}$ \\
\hline Roots & $0.82 \pm 0.14 \mathrm{c}$ & $0.107 \pm 0.007 \mathrm{~d}$ & $1.61 \pm 0.06 \mathrm{bc}$ & $0.13 \pm 0.01 \mathrm{~b}$ & $0.16 \pm 0.05 c$ & $13.8 \pm 2.0 \mathrm{a}$ \\
\hline \multirow[t]{2}{*}{ Whole palm } & $1.21 \pm 0.12 \mathrm{bc}$ & $0.150 \pm 0.007 \mathrm{~cd}$ & $1.62 \pm 0.07 \mathrm{bc}$ & $0.16 \pm 0.01 \mathrm{~b}$ & $0.26 \pm 0.02 \mathrm{bc}$ & $9.5 \pm 0.2 \mathrm{bcd}$ \\
\hline & \multicolumn{6}{|c|}{ Immature palms (29-48 months old) } \\
\hline Spear leaves & $1.71 \pm 0.09 \mathrm{ab}$ & $0.291 \pm 0.015 \mathrm{ab}$ & $2.07 \pm 0.09 c$ & $0.26 \pm 0.02 \mathrm{bcd}$ & $0.39 \pm 0.02 \mathrm{~cd}$ & $11.2 \pm 1.3 \mathrm{bcd}$ \\
\hline Leaflets & $2.09 \pm 0.18 \mathrm{a}$ & $0.165 \pm 0.010 \mathrm{bc}$ & $1.03 \pm 0.04 \mathrm{de}$ & $0.29 \pm 0.04 \mathrm{bc}$ & $0.62 \pm 0.06 \mathrm{~b}$ & $10.7 \pm 0.9 \mathrm{bcd}$ \\
\hline Rachis & $0.36 \pm 0.05 c$ & $0.090 \pm 0.021 \mathrm{c}$ & $1.27 \pm 0.11$ cde & $0.12 \pm 0.02 \mathrm{~cd}$ & $0.29 \pm 0.03 \mathrm{de}$ & $5.3 \pm 0.5 \mathrm{e}$ \\
\hline Petiole & $0.49 \pm 0.05 c$ & $0.122 \pm 0.015 c$ & $1.76 \pm 0.14 \mathrm{~cd}$ & $0.17 \pm 0.01 \mathrm{~cd}$ & $0.34 \pm 0.03 \mathrm{~d}$ & $9.6 \pm 0.9 \mathrm{~d}$ \\
\hline Leaf bases & $0.51 \pm 0.10 c$ & $0.112 \pm 0.020 \mathrm{bc}$ & $1.75 \pm 0.28$ cde & $0.26 \pm 0.03 \mathrm{bcd}$ & $0.25 \pm 0.02 \mathrm{de}$ & $14.6 \pm 1.3 \mathrm{abc}$ \\
\hline Cabbage & $2.45 \pm 0.47 \mathrm{a}$ & $0.363 \pm 0.066 \mathrm{a}$ & $5.06 \pm 0.42 \mathrm{a}$ & $0.90 \pm 0.03 \mathrm{a}$ & $0.90 \pm 0.03 \mathrm{a}$ & $17.9 \pm 1.2 \mathrm{a}$ \\
\hline Trunk & $1.75 \pm 0.34 \mathrm{ab}$ & $0.336 \pm 0.075 \mathrm{a}$ & $3.48 \pm 0.46 \mathrm{~b}$ & $0.40 \pm 0.10 b$ & $0.59 \pm 0.11 \mathrm{bc}$ & $14.0 \pm 0.6 \mathrm{ab}$ \\
\hline Bole & $0.82 \pm 0.18 c$ & $0.123 \pm 0.032 c$ & $1.59 \pm 0.22$ cde & $0.09 \pm 0.02 \mathrm{~d}$ & $0.29 \pm 0.02 \mathrm{de}$ & $9.1 \pm 0.6 \mathrm{~d}$ \\
\hline Roots & $0.42 \pm 0.07 c$ & $0.067 \pm 0.011 c$ & $0.86 \pm 0.09 \mathrm{e}$ & $0.08 \pm 0.01 \mathrm{~d}$ & $0.09 \pm 0.01 \mathrm{e}$ & $4.9 \pm 0.6 \mathrm{e}$ \\
\hline \multirow[t]{2}{*}{ Whole palm } & $1.07 \pm 0.11 \mathrm{bc}$ & $0.159 \pm 0.017 \mathrm{bc}$ & $1.76 \pm 0.09 \mathrm{~cd}$ & $0.22 \pm 0.03 \mathrm{bcd}$ & $0.42 \pm 0.03 \mathrm{bcd}$ & $10.1 \pm 0.6 \mathrm{~cd}$ \\
\hline & \multicolumn{6}{|c|}{ Mature palms (88-238 months old) } \\
\hline Spear leaves & $1.14 \pm 0.07 \mathrm{c}$ & $0.150 \pm 0.006 \mathrm{~b}$ & $2.02 \pm 0.07 \mathrm{bc}$ & $0.16 \pm 0.01 \mathrm{bc}$ & $0.28 \pm 0.01 \mathrm{~d}$ & $10.5 \pm 0.7 \mathrm{bc}$ \\
\hline Leaflets & $1.81 \pm 0.06 \mathrm{~b}$ & $0.123 \pm 0.004 b c$ & $1.00 \pm 0.03 \mathrm{de}$ & $0.20 \pm 0.01 \mathrm{~b}$ & $0.54 \pm 0.02 b$ & $12.5 \pm 0.7 \mathrm{~b}$ \\
\hline Rachis & $0.25 \pm 0.02 \mathrm{~g}$ & $0.065 \pm 0.007 \mathrm{def}$ & $1.61 \pm 0.09 \mathrm{~cd}$ & $0.07 \pm 0.004 \mathrm{e}$ & $0.30 \pm 0.02 \mathrm{~d}$ & $6.4 \pm 0.4 \mathrm{de}$ \\
\hline Petiole & $0.42 \pm 0.02 \mathrm{efg}$ & $0.097 \pm 0.009 \mathrm{~cd}$ & $2.32 \pm 0.10 \mathrm{bc}$ & $0.14 \pm 0.01 \mathrm{bcd}$ & $0.42 \pm 0.03 c$ & $11.1 \pm 0.6 \mathrm{bc}$ \\
\hline Leaf bases & $0.55 \pm 0.04 \mathrm{def}$ & $0.078 \pm 0.010 \mathrm{cde}$ & $2.03 \pm 0.15 b c$ & $0.20 \pm 0.02 \mathrm{~b}$ & $0.31 \pm 0.04 \mathrm{~cd}$ & $8.9 \pm 0.7 \mathrm{~cd}$ \\
\hline Cabbage & $2.39 \pm 0.11 \mathrm{a}$ & $0.417 \pm 0.029 \mathrm{a}$ & $5.03 \pm 0.23 \mathrm{a}$ & $0.68 \pm 0.04 \mathrm{a}$ & $0.82 \pm 0.05 \mathrm{a}$ & $21.5 \pm 0.9 \mathrm{a}$ \\
\hline Trunk & $0.65 \pm 0.06 \mathrm{de}$ & $0.091 \pm 0.008 \mathrm{cde}$ & $2.50 \pm 0.35 b$ & $0.09 \pm 0.004$ cde & $0.26 \pm 0.02 \mathrm{~d}$ & $8.4 \pm 0.8 \mathrm{~cd}$ \\
\hline Bole & $0.49 \pm 0.07 \mathrm{defg}$ & $0.045 \pm 0.007$ ef & $1.98 \pm 0.16 \mathrm{bc}$ & $0.08 \pm 0.01 \mathrm{de}$ & $0.29 \pm 0.01 \mathrm{~d}$ & $8.4 \pm 0.7 \mathrm{~cd}$ \\
\hline Roots & $0.33 \pm 0.02 \mathrm{~b}$ & $0.022 \pm 0.003 \mathrm{f}$ & $0.66 \pm 0.06 \mathrm{e}$ & $0.06 \pm 0.004 \mathrm{e}$ & $0.06 \pm 0.01 \mathrm{e}$ & $4.8 \pm 0.4 \mathrm{e}$ \\
\hline Whole palm & $0.70 \pm 0.03 b$ & $0.090 \pm 0.006$ cde & $2.02 \pm 0.15 b c$ & $0.13 \pm 0.004$ cde & $0.32 \pm 0.01 \mathrm{~cd}$ & $9.0 \pm 0.3 \mathrm{~cd}$ \\
\hline
\end{tabular}

Means sharing the same letter within each nutrient element are not significantly different at $p \leq 0.05$. Cabbage tissue of nursery seedlings was not separated but treated as bole tissue since it is difficult in practice to separate them. No leaf bases and trunk tissue were recovered from nursery seedlings.

Table 6. Concentrations (mean $\pm \mathrm{SE}$ ) of $\mathrm{N}, \mathrm{P}, \mathrm{K}, \mathrm{Mg}$, Ca, and B of nursery, immature, and mature oil palms. Other studies did not report their SE values.

\begin{tabular}{|c|c|c|c|c|c|c|c|}
\hline \multirow{2}{*}{$\begin{array}{l}\text { Planting } \\
\text { Material }\end{array}$} & \multicolumn{5}{|c|}{$\%$ of Dry Matter } & \multirow{2}{*}{$\begin{array}{c}\mathrm{mg} \mathrm{kg}^{-1} \\
\mathrm{~B}\end{array}$} & \multirow[b]{2}{*}{ Reference } \\
\hline & $\mathbf{N}$ & $\mathbf{P}$ & $\mathbf{K}$ & Mg & $\mathrm{Ca}$ & & \\
\hline & \multicolumn{6}{|c|}{ Nursery seedlings (12 months old) } & \multirow{3}{*}{$\begin{array}{c}\text { This study } \\
\text { [2] }\end{array}$} \\
\hline $\begin{array}{l}\text { Tenera } \\
\text { Tenera }\end{array}$ & $\begin{array}{c}1.21 \pm 0.12 \\
1.37\end{array}$ & $\begin{array}{c}0.150 \pm 0.007 \\
0.147\end{array}$ & $\begin{array}{c}1.62 \pm 0.07 \\
1.48\end{array}$ & $\begin{array}{c}0.16 \pm 0.01 \\
0.22\end{array}$ & $\begin{array}{c}0.26 \pm 0.02 \\
0.14\end{array}$ & $\begin{array}{c}9.5 \pm 0.2 \\
-\end{array}$ & \\
\hline & \multicolumn{6}{|c|}{ Immature palms (29-48 months old) } & \\
\hline $\begin{array}{l}\text { Tenera } \\
\text { Tenera }\end{array}$ & $\begin{array}{c}1.07 \pm 0.11 \\
0.85\end{array}$ & $\begin{array}{c}0.159 \pm 0.017 \\
0.098\end{array}$ & $\begin{array}{c}1.76 \pm 0.09 \\
1.53\end{array}$ & $\begin{array}{c}0.22 \pm 0.03 \\
0.22\end{array}$ & $\begin{array}{c}0.42 \pm 0.03 \\
0.14\end{array}$ & $\begin{array}{c}10.1 \pm 0.6 \\
-\end{array}$ & \multirow[t]{2}{*}{$\begin{array}{c}\text { This study } \\
\text { [2] }\end{array}$} \\
\hline & \multicolumn{6}{|c|}{ Mature palms (88-238 months old) } & \\
\hline Tenera & $0.70 \pm 0.03$ & $0.090 \pm 0.006$ & $2.02 \pm 0.15$ & $0.13 \pm 0.04$ & $0.32 \pm 0.01$ & $9.0 \pm 0.3$ & \multirow{3}{*}{$\begin{array}{c}\text { This study } \\
{[2]} \\
{[4,5,18]}\end{array}$} \\
\hline Dura & $0.53-0.65$ & $0.052-0.105$ & $1.48-1.72$ & $0.16-0.20$ & $0.17-0.20$ & - & \\
\hline Tenera & $0.38-0.57$ & $0.052-0.063$ & $1.22-1.86$ & - & - & - & \\
\hline
\end{tabular}


Table 7. Pearson correlations between tissues' nutrient concentration with palm age in 12-to-238-month-old tenera oil palm. Values presented are correlation coefficients. ${ }^{*} p<0.05$; ns $p>0.05$.

\begin{tabular}{cccc}
\hline Nutrient & Leaves & Trunk & Whole Palm \\
\hline $\mathrm{N}$ & $-0.56^{*}$ & $-0.59^{*}$ & $-0.70^{*}$ \\
$\mathrm{P}$ & $-0.54^{*}$ & $-0.60^{*}$ & $-0.69^{*}$ \\
$\mathrm{~K}$ & $0.06^{\mathrm{ns}}$ & $0.34^{\mathrm{ns}}$ & $0.05^{\mathrm{ns}}$ \\
$\mathrm{Mg}$ & $0.53^{*}$ & $-0.50^{*}$ & $-0.65^{*}$ \\
$\mathrm{Ca}$ & $0.03^{\mathrm{ns}}$ & $-0.44^{*}$ & $-0.44^{*}$ \\
$\mathrm{~B}$ & $0.22^{\mathrm{ns}}$ & $-0.62^{*}$ & $-0.44^{*}$ \\
\hline
\end{tabular}

Table 8. Nutrient concentrations (mean \pm SE) in fresh fruit bunches and their components in tenera oil palm. ( $n=22$ ripe bunches harvested from different ages of palms).

\begin{tabular}{lcccccc}
\hline \multirow{2}{*}{$\begin{array}{l}\text { Bunch } \\
\text { Component }\end{array}$} & \multicolumn{3}{c}{ \% of Dry Matter } & \multicolumn{2}{c}{$\mathbf{m g ~ k g}^{-\mathbf{1}}$} \\
\cline { 2 - 7 } & $\mathbf{N}$ & $\mathbf{P}$ & $\mathbf{K}$ & $\mathbf{M g}$ & $\mathbf{C a}$ & $\mathbf{B}$ \\
\hline Stalk & $0.84 \pm 0.04 \mathrm{~b}$ & $0.127 \pm 0.011 \mathrm{~b}$ & $3.98 \pm 0.19 \mathrm{a}$ & $0.14 \pm 0.01 \mathrm{c}$ & $0.43 \pm 0.03 \mathrm{bc}$ & $13.9 \pm 0.6 \mathrm{a}$ \\
Spikelet & $0.84 \pm 0.06 \mathrm{~b}$ & $0.116 \pm 0.008 \mathrm{~b}$ & $1.84 \pm 0.11 \mathrm{~b}$ & $0.21 \pm 0.02 \mathrm{bc}$ & $0.36 \pm 0.03 \mathrm{bcd}$ & $13.4 \pm 1.2 \mathrm{a}$ \\
Mesocarp & $0.93 \pm 0.10 \mathrm{~b}$ & $0.141 \pm 0.017 \mathrm{~b}$ & $1.20 \pm 0.17 \mathrm{c}$ & $0.38 \pm 0.05 \mathrm{a}$ & $0.73 \pm 0.11 \mathrm{a}$ & $13.0 \pm 1.3 \mathrm{a}$ \\
Kernel & $1.67 \pm 0.11 \mathrm{a}$ & $0.378 \pm 0.034 \mathrm{a}$ & $0.55 \pm 0.07 \mathrm{~d}$ & $0.20 \pm 0.02 \mathrm{bc}$ & $0.20 \pm 0.03 \mathrm{~cd}$ & $5.8 \pm 0.8 \mathrm{~b}$ \\
Shell & $0.64 \pm 0.09 \mathrm{~b}$ & $0.105 \pm 0.020 \mathrm{~b}$ & $0.48 \pm 0.05 \mathrm{~d}$ & $0.11 \pm 0.01 \mathrm{c}$ & $0.15 \pm 0.02 \mathrm{~d}$ & $6.8 \pm 0.7 \mathrm{~b}$ \\
Whole bunch & $0.90 \pm 0.06 \mathrm{~b}$ & $0.150 \pm 0.011 \mathrm{~b}$ & $1.20 \pm 0.10 \mathrm{c}$ & $0.25 \pm 0.02 \mathrm{~b}$ & $0.44 \pm 0.05 \mathrm{~b}$ & $11.1 \pm 0.8 \mathrm{a}$ \\
\hline
\end{tabular}

Means sharing the same letter within each nutrient element are not significantly different at $p \leq 0.05$.

Table 9. Nutrient contents (mean $\pm \mathrm{SE}$ ) in dura and tenera fresh fruit bunches. Other studies did not report their SE values.

\begin{tabular}{|c|c|c|c|c|c|c|}
\hline \multirow{2}{*}{$\begin{array}{l}\text { Bunch } \\
\text { Type }\end{array}$} & \multicolumn{5}{|c|}{ Nutrient Content (kg t ${ }^{-1}$ FFB) } & \multirow{2}{*}{ Reference } \\
\hline & $\mathbf{N}$ & $\mathbf{P}$ & $\mathbf{K}$ & $\mathrm{Mg}$ & $\mathrm{Ca}$ & \\
\hline Dura & 2.94 & 0.44 & 3.71 & 0.81 & - & [33] \\
\hline Tenera & 3.10 & 0.37 & 3.92 & 0.68 & - & [6] \\
\hline Tenera & 5.03 & 0.66 & 5.26 & 0.76 & - & [19] \\
\hline Tenera & 3.07 & 0.38 & 3.84 & 0.62 & 0.51 & [20] \\
\hline Tenera & $4.74 \pm 0.31$ & $0.79 \pm 0.06$ & $6.35 \pm 0.50$ & $1.31 \pm 0.10$ & $2.30 \pm 0.27$ & This study \\
\hline
\end{tabular}

\subsection{Nutrient Demand}

The annual demand of $\mathrm{N}, \mathrm{P}, \mathrm{Mg}, \mathrm{Ca}$, and $\mathrm{B}$ for vegetative growth tended to follow annual vegetative dry-matter production (Figure 3; Table 4), with low demand during the first 12 months of growth. However, thereafter, nutrient demand increased rapidly up to 88 months after nursery planting, and with slower increase thereafter up to month 209, before declining to a lower demand at month 238. Annual vegetative growth demand for $\mathrm{K}$ was slightly different, as $\mathrm{K}$ demand declined sharply after peaking at month 88 , and only reverted upward at month 238. Annual fruit-bunch demand for $\mathrm{N}, \mathrm{P}, \mathrm{K}, \mathrm{Mg}, \mathrm{Ca}$, and $\mathrm{B}$ closely followed annual fruit-bunch production (Figure 3; Table 4), with a steady increase from 48 months after nursery planting, up to month 209 when fruit-bunch production peaked. Thereafter, nutrient demand declined following lower fruit-bunch production. Annual total nutrient demand appeared to follow nutrient demand for vegetative growth, with maximum nutrient demand occurring at month 209 when fruit bunch-production reached its peak-except for $\mathrm{K}$ demand, which occurred at month 88 , when vegetative growth demand for K peaked (Figure 3). At 12 months old, the total nutrient demand of the tenera oil palm was $18 \mathrm{~g} \mathrm{~N}, 2.3 \mathrm{~g} \mathrm{P}, 25 \mathrm{~g} \mathrm{~K}, 2.5 \mathrm{~g} \mathrm{Mg}, 4.1 \mathrm{~g} \mathrm{Ca}$, and $0.01 \mathrm{~g}$ B per palm. However, its annual nutrient demand increased substantially to its maximum at $2.34 \mathrm{~kg} \mathrm{~N}$, $0.35 \mathrm{~kg} \mathrm{P}, 4.36 \mathrm{~kg} \mathrm{~K}, 0.50 \mathrm{~kg} \mathrm{Mg}, 1.14 \mathrm{~kg} \mathrm{Ca}$, and $3.0 \mathrm{~g} \mathrm{~B}$ per palm. These amounts of nutrients are sufficient to meet annual fruit-bunch production of $30 \mathrm{t} \mathrm{ha}^{-1}$. 

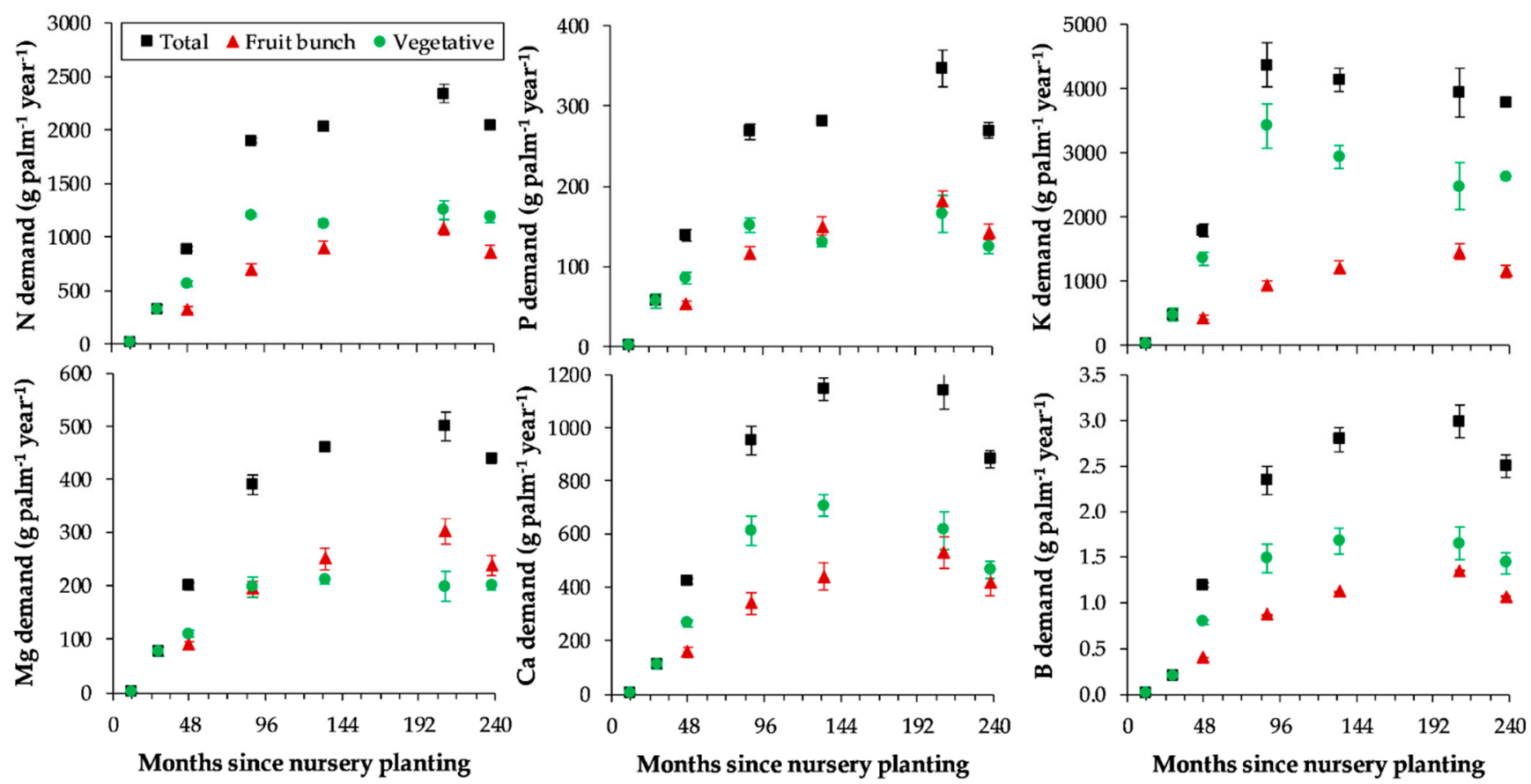

Figure 3. Mean amounts of $\mathrm{N}, \mathrm{P}, \mathrm{K}, \mathrm{Mg}, \mathrm{Ca}$, and $\mathrm{B}$ required to meet nutrient demand for vegetative growth and fruit-bunch production of tenera oil palm of different ages sampled in this study. Error bars are standard errors.

During the entire duration of 238 months of palm growth, $\mathrm{K}$ was the most required nutrient, which accounted for about $54 \%$ of total nutrient demand, followed by $\mathrm{N}$ at about $25 \%$, while $\mathrm{P}, \mathrm{Mg}$, and $\mathrm{Ca}$ accounted for about 4,6 , and $12 \%$ of total nutrient demand, respectively. Not surprisingly, as it is a micronutrient, $\mathrm{B}$ demand was the lowest, at about $0.03 \%$. Of the measured nutrients, between 37 and $54 \%$ of $\mathrm{N}, \mathrm{P}, \mathrm{Mg}, \mathrm{Ca}$, and $\mathrm{B}$ taken up by the tenera palms across different ages was partitioned to fruit bunches; except for $\mathrm{K}$, which was lower (ranged between 19 and 36\%) (Table 10).

Table 10. Proportion of nutrients (mean \pm SE) partitioned to fruit bunches in tenera oil palms of different ages. Palm age is given in number of months since nursery planting.

\begin{tabular}{ccccccc}
\hline Palm Age & \multicolumn{6}{c}{ Proportion of Nutrients Partitioned to Fruit Bunches (\%) } \\
\hline & N & P & K & Mg & Ca & B \\
\hline 48 & $35 \pm 1 \mathrm{~b}$ & $37 \pm 2 \mathrm{~b}$ & $23 \pm 1 \mathrm{~b}$ & $42 \pm 1 \mathrm{~b}$ & $36 \pm 2 \mathrm{c}$ & $31 \pm 1 \mathrm{~b}$ \\
88 & $37 \pm 2 \mathrm{~b}$ & $43 \pm 2 \mathrm{ab}$ & $19 \pm 2 \mathrm{~b}$ & $50 \pm 2 \mathrm{ab}$ & $38 \pm 4 \mathrm{c}$ & $38 \pm 3 \mathrm{ab}$ \\
133 & $45 \pm 2 \mathrm{a}$ & $52 \pm 2 \mathrm{a}$ & $27 \pm 1 \mathrm{~b}$ & $49 \pm 3 \mathrm{~b}$ & $42 \pm 4 \mathrm{bc}$ & $40 \pm 2 \mathrm{ab}$ \\
209 & $48 \pm 3 \mathrm{a}$ & $52 \pm 4 \mathrm{a}$ & $37 \pm 4 \mathrm{a}$ & $58 \pm 2 \mathrm{a}$ & $50 \pm 6 \mathrm{a}$ & $47 \pm 3 \mathrm{a}$ \\
238 & $45 \pm 1 \mathrm{a}$ & $53 \pm 3 \mathrm{a}$ & $27 \pm 1 \mathrm{~b}$ & $58 \pm 1 \mathrm{a}$ & $49 \pm 3 \mathrm{ab}$ & $45 \pm 2 \mathrm{a}$ \\
\hline
\end{tabular}

Means sharing the same letter within each nutrient element are not significantly different at $p \leq 0.05$.

\section{Discussion}

\subsection{Standing Vegetative Biomass and Dry-Matter Production}

The aboveground dry weight of tenera palms measured in this study were comparable to previous studies on either dura or tenera palms grown on different soils and under different management practices in Malaysia [16,18,34] and in Indonesia [35,36] (Figure S2). Our results suggest that accumulation of aboveground vegetative biomass in oil palm tends to remain relatively constant across different types of planting materials and environments. However, clear differences in aboveground vegetative biomass accumulation were observed on palms grown under suboptimal conditions such as peat in Malaysia [37] and in West Africa $[15,38]$. The poor growing conditions of peat $[39,40]$ and marked dry seasons 
prevailing in West Africa [41] would have detrimentally affected the growth of the sampled palms there; hence, they accumulated less aboveground vegetative biomass.

The rapid increase in dry-matter production during the first 88 months of planting is typical of oil palm and is consistent with previous studies $[2,16]$. Production of aboveground vegetative dry matter in mature palms was in close agreement with studies conducted in Malaysia [2,16] but was much higher than in oil palms studied in West Africa $[15,38]$ (Table S3). Seasonal drought (6 consecutive months with monthly mean rainfall of less than $100 \mathrm{~mm}$ per month ${ }^{-1}$ ) [11] in West Africa would have affected the rate of leaf production and expansion [36,42], and in turn resulted in lower leaf dry-matter production. $\mathrm{Ng}$ et al. [2], on the other hand, might have underestimated leaf dry-matter production by only considering 18 pruned leaves with average leaf dry weight of $3.95 \mathrm{~kg}$ while overestimating trunk dry-matter production by including leaf bases as part of the trunk.

If root dry-matter production is considered, the total vegetative dry-matter production estimated in this study agreed with Dufrene's estimation [38] of $171.3 \mathrm{~kg} \mathrm{palm}^{-1}$ year $^{-1}$, but this was about $25 \%$ higher than Corley et al. [16] and 75\% higher than Rees and Tinker [15]. Dufrene [38] and this study estimated annual root dry-matter production, but the other studies only considered net increase in root dry weight, and this perhaps explains the observed differences. If Equation (4), which was developed in Malaysia, was used to estimate the root dry-matter production in Corley et al. [16], then total vegetative dry-matter production would be increased to $144.7 \mathrm{~kg} \mathrm{palm}^{-1}$ year ${ }^{-1}$, quite close to the present estimate of $168.2 \mathrm{~kg} \mathrm{palm}^{-1}$ year $^{-1}$ (Table S3). It is thus obvious that production of vegetative dry matter could be quite similar across different environments, but the partitioning of above- and belowground vegetative dry matter might vary depending on the prevailing growing conditions. Dufrene [38] showed that oil palm tends to partition more dry matter to roots in places with pronounced dry seasons. In this study, the root dry-matter production was estimated using Equation (4) developed in Malaysia [31]. The estimated root dry-matter production only represents about $10.4 \%$ of total aboveground vegetative dry-matter production. This is a considerably small fraction of dry matter partitioned to the roots as argued by Corley and Tinker [11] (pp. 341-342). Thus, it seems that further studies are required to ascertain root dry-matter production of tenera palms at different ages of growth, since this has important implication on total dry-matter production, partitioning, and vegetative growth demand for nutrients.

Bunch dry matter produced in this study was comparable to the amounts produced elsewhere in Malaysia but was 1.6 to 2 times more than those in West Africa (Table S3). This is not unexpected, as dry-matter requirements for vegetative growth appear to be met first before any surplus dry matter is diverted to bunch production. This surplus is smaller in less-conducive environments like West Africa, where a marked dry season prevails. Consequently, total dry-matter production across different environments might not vary as substantially as highlighted here. Total dry-matter production found in this study was only $15 \%$ more than Dufrene [38], despite having produced $61 \%$ more bunch dry matter.

\subsection{Nutrient Concentrations and Nutrient Demand}

The variations in nutrient concentrations among vegetative tissues found in this study were consistent with previous studies $[2,4,5,17,18,21,43]$. These results confirm that the uptake of nutrients cannot be reliably deduced from leaf nutrient analysis alone [43], as high concentrations of nutrients are also found in other vegetative tissues such as rachis, petiole, leaf bases, and trunk. Classical fertilizer recommendation methodology based solely on leaf nutrient analysis data must consider the variations in nutrient concentrations among vegetative tissues. Considerable palm-to-palm variations in nutrient concentrations might be attributed to genetic differences, since tenera palms planted at the study site came from different genetic origins. It has been shown that nutrient uptake could vary by up to $30-40 \%$ among oil-palm planting materials [43]. It is also possible that the variations observed were caused by genetic-environmental interactions. We therefore recommend establishing plantations with blocks of homogenous oil-palm planting materials in order to 
obtain a more reliable estimate of fertilizer requirements. In the case of existing plantations with mixed oil-palm planting materials, an appropriate sampling size should be established for every management block so as to minimize variation.

Much higher nutrient concentrations found in the cabbage were expected and have been documented $[2,21]$. This plant part is the growing point of the palm, so it is not surprising to observe a much higher concentration of nutrients here, as more nutrients are required to grow developing tissues, such as immature leaves and leaf bases. Higher $\mathrm{K}$ concentrations found in all vegetative tissues, particularly in the trunk, agreed with previous findings $[2,18,43,44]$, and confirmed its prominent role in the nutrition of oil palm. The high concentrations of nutrients found in the leaf bases highlight the importance of this plant part as nutrient sink and stock, and it should be given due attention since it constitutes a significant portion of vegetative biomass (Table 2). The amounts of nutrients immobilized by leaf bases and recycled back to the soil through shedding of leaf bases could be significant [45]. The low nutrient concentrations found in the roots have been reported $[2,4,5,21]$.

The higher concentrations of $\mathrm{N}, \mathrm{P}, \mathrm{K}, \mathrm{Mg}$, and $\mathrm{Ca}$ found in the whole immature and mature tenera studied here (Table 6), suggest that the tenera studied here might require more $\mathrm{N}, \mathrm{P}, \mathrm{K}, \mathrm{Mg}$, and $\mathrm{Ca}$ to sustain vegetative growth for a same unit of biomass produced. Recent advances in agronomic practices might have improved the uptake of nutrients, and led to the observed higher concentrations of $\mathrm{N}, \mathrm{P}, \mathrm{K}, \mathrm{Mg}$, and $\mathrm{Ca}$. It is also possible that the presently studied tenera had higher nutrient concentrations in its vegetative tissues intrinsically as a result of advances in oil-palm breeding [43].

The decline in concentrations of $\mathrm{N}$ and $\mathrm{P}$ with age, particularly in the trunk, has been reported [2]. Henson and Chang [46] analyzed published nutrient concentration data and found that only concentrations of $\mathrm{N}$ and $\mathrm{P}$ in the trunk declined with age, while $\mathrm{N}, \mathrm{P}$, and $\mathrm{K}$ concentrations in other palm tissues did not. The present study confirmed their findings but also found that concentrations of $\mathrm{N}$ and $\mathrm{P}$ in the leaves, concentration of $\mathrm{Mg}$ in the leaves and trunk, and concentrations of $\mathrm{Ca}$ and $\mathrm{B}$ in the trunk declined with age (Table 7). The ability of oil palm to store $\mathrm{K}$ in vegetative tissues might explain the lack of correlation between $\mathrm{K}$ concentration and palm age $[18,44]$. This is supported by higher $\mathrm{K}$ concentrations found in the vegetative tissues such as rachis, petiole, leaf bases, trunk, and bole (Table 5). If whole-palm nutrient concentration is considered, only $\mathrm{K}$ concentration did not decline with age (Table 7). The physiological mechanism underlying the decline in concentration of nutrients in plant tissues with plant or organ age is complex and has not been fully understood [47]. One plausible explanation is that as the plant grows and accumulates more biomass, the increase in plant or organ biomass is greater than the corresponding increase in nutrient content. This eventually decreases the concentration of nutrients due to the dilution effect of biomass $[47,48]$. Trunk $\mathrm{K}$ behaved quite differently in relation to palm age. It tended to increase with palm age initially before declining to a more stable level (Figure S3). Ng et al. [2] observed a similar trend of K concentration in the trunk (Figure S3). They argued that oil palm tends to build up a K reserve in the trunk during the early years of planting, but this reserve will deplete gradually soon after fruit-bunch production peaks. The present observation seems to agree with $\mathrm{Ng}$ et al. [2] as $\mathrm{K}$ concentration in the trunk tended to decrease with increasing fruit-bunch yield in both studies.

The variations in nutrient concentrations among bunch components found in this study were consistent with previous studies $[6,19-21,33]$. The most striking variation is the nutrient concentrations in the mesocarp. The tenera bunches studied here had much higher $\mathrm{N}, \mathrm{P}, \mathrm{K}, \mathrm{Mg}$, and Ca concentrations in their mesocarps than previously studied dura and tenera bunches (Table 8). Consequently, the tenera bunches studied here contain higher $\mathrm{N}$, $\mathrm{P}, \mathrm{K}, \mathrm{Mg}$, and Ca contents than previously studied dura and tenera bunches (Table 9). It is thus obvious that for the same production level of fruit bunches, the tenera studied here would require more nutrients to support fruit-bunch production.

The rapid increase in nutrient demand in the first 88 months since nursery planting was mainly driven by growth rate (Table 4), consistent with $\mathrm{Ng}$ et al. [2] and Goh et al. [21], 
and also suggests that derivation of nutrient requirements from palms of one age or from mature palms alone appears inadequate. Higher demand of N, P, Mg, Ca, and B at month 209 was attributed to high demand of these nutrients for fruit-bunch production (Figure 3; Table 4). The decline in $\mathrm{K}$ demand for vegetative growth after month 88 was consistent with the decline in trunk $\mathrm{K}$ concentration (Figures 3 and S3). It appears that the studied tenera did not increase its $\mathrm{K}$ uptake when fruit-bunch demand for $\mathrm{K}$ increased due to increasing fruit-bunch production but instead used $\mathrm{K}$ reserved in the vegetative tissues, particularly trunk $\mathrm{K}$, to meet fruit-bunch production. Thus, it is important to build up $\mathrm{K}$ reserves during the early years of planting to meet increased $\mathrm{K}$ demand in later years. Teoh and Chew [18] estimated that trunk K reserve of fully fertilized tenera palms could support vegetative growth and fruit-bunch production for 2 to 6 years.

The substantial amounts of nutrients required annually by the tenera studied here reemphasize the large fertilizer needs of oil palm and the importance of judicious manuring that meets agronomic, economic, and environmental objectives. The amounts of nutrients depicted in Figure 3 were regarded as gross nutrient demand [2,11] since nutrients recycled from pruned leaves were not considered. If annual fruit-bunch production of $25 \mathrm{tha}^{-1}$ is considered, the annual gross nutrient demand of mature tenera studied here would be $1.99 \mathrm{~kg} \mathrm{~N}, 0.28 \mathrm{~kg} \mathrm{P}, 3.94 \mathrm{~kg} \mathrm{~K}, 0.42 \mathrm{~kg} \mathrm{Mg}$, and $0.99 \mathrm{~kg} \mathrm{Ca} \mathrm{palm}^{-1}$ which is about $53,57,132$, and $64 \%$ more N, P, K, and Ca than found in the dura studied by Ng et al. [2], respectively, but $\mathrm{Mg}$ demand was only $2 \%$ higher than in the dura. No difference was found when annual B demand was compared with another mature tenera [21], as both required $2.5 \mathrm{~g} \mathrm{palm}^{-1}$

However, if nutrients contained in the pruned leaves were all recycled, the annual net demand of nutrients would be $1.04 \mathrm{~kg} \mathrm{~N}, 0.16 \mathrm{~kg} \mathrm{P}, 1.85 \mathrm{~kg} \mathrm{~K}, 0.26 \mathrm{~kg} \mathrm{Mg}, 0.47 \mathrm{~kg} \mathrm{Ca}$, and $1.3 \mathrm{~g} \mathrm{~B} \mathrm{palm}^{-1}$. These amounts were higher than net nutrient demand of fully fertilized mature dura [2] and tenera [18] studied previously. Teoh and Chew [18] found that fully fertilized mature tenera grown on different soils in Malaysia required 1.34 to $1.59 \mathrm{~kg} \mathrm{~K} \mathrm{palm}^{-1}$ year $^{-1}$ if $\mathrm{K}$ recycled from pruned leaves was considered. The higher nutrient demand is not unexpected because of higher nutrient concentrations found in the vegetative tissues and fruit bunches of tenera studied here, and given that dry-matter production of either dura or tenera planting materials could be quite similar, especially when they are grown under favorable environments (Table S3). Therefore, for the same level of dry-matter production, the tenera studied here would need more nutrients.

Fruit bunches accounted for the largest portion of required $\mathrm{N}, \mathrm{P}, \mathrm{Mg}, \mathrm{Ca}$, and $\mathrm{B}$, except in the case of $\mathrm{K}$ (Table 9), because a large portion of $\mathrm{K}$ is stored in vegetative tissues such as leaves, trunk, and leaf bases (Table 6). Goh et al. [44] found that fully fertilized mature tenera grown on different soils in Malaysia partitioned $70-73 \%$ of their $\mathrm{K}$ demand to vegetative tissues, whereas unfertilized tenera partitioned $55-70 \%$. Thus, from the fertilizer management context, the production level of fruit bunches has great influence on the determination of fertilizer requirements of oil palm.

\subsection{Implications on Fertilizer Requirements of Oil Palm}

The tenera studied here has been fertilized following standard commercial fertilizer regimes that are commonly practiced in the palm-oil industry in Malaysia (Table 1). The vegetative dry matter and fruit-bunch production of this tenera was comparable to fully fertilized tenera studied in Malaysia $[4,5,16]$, suggesting that the tenera studied here must be growing at its potential. The tenera were neither deficient nor luxuriant in nutrient content since the net amounts of nutrients required for vegetative growth and fruit-bunch production closely matched the applied fertilizer quantities after accounting for losses to the environments [49,50] (Table S4). The small deficit of about $46 \mathrm{~kg} \mathrm{~N}, 54 \mathrm{~kg} \mathrm{~K}$, and $11 \mathrm{~kg}$ Mg per hectare per year could be easily supplied by Harimau Series soil (Typic Paleudult). Soils in Malaysia could supply 90 to $194 \mathrm{~kg} \mathrm{~N}$ and 62 to $189 \mathrm{~kg} \mathrm{~K}$ per hectare per year $[4,44]$. Therefore, the growth demand for nutrients determined in this study could serve as the potential nutrient demand of tenera oil palm grown under current agronomic 
practices in Malaysia, and perhaps elsewhere. The nutrient demand data obtained here can be used together with soil and foliar nutrient analysis data to further refine the fertilizer requirements for tenera oil palm grown on different soil types.

\section{Conclusions}

The present study closes a significant gap in the nutrient management of tenera oil palm grown under current agronomic practices, by determining its nutrient demand at different ages of growth.

Although the dry-matter production of commercially grown tenera has not increased over the years, its $\mathrm{N}, \mathrm{P}, \mathrm{K}, \mathrm{Mg}, \mathrm{Ca}$, and $\mathrm{B}$ concentrations in vegetative tissues and fruit bunches were found to be higher. This has led to higher demand of these nutrients, which should be given due attention when formulating fertilizer requirements for tenera grown under current agronomic practices. The present findings provide an opportunity to match the nutrient demand of tenera at different ages of growth. This allows more sustainable production of palm oil that meets agronomic, economic and environmental objectives. Important findings of this study are summarized below.

(1) Excluding roots, the total standing vegetative biomass increased almost linearly from $1.3 \mathrm{~kg} \mathrm{palm}^{-1}$ at 12 months old to $808.6 \mathrm{~kg} \mathrm{palm}^{-1}$ at 238 months old.

(2) Whole palm dry-matter production increased with palm age but at a decreasing rate, from $1.5 \mathrm{~kg} \mathrm{palm}^{-1}$ year $^{-1}$ at 12 months old to $285.5 \mathrm{~kg} \mathrm{palm}^{-1}$ year $^{-1}$ after 133 months, with little increase thereafter.

(3) Nutrient concentrations in vegetative tissues varied considerably depending on palm age, nutrient element, and tissue types. The tenera studied here generally had higher nutrient concentrations in the vegetative tissues and fruit bunches than previously studied dura and tenera.

(4) The maximum N, P, Mg, Ca, and B demand occurred at month 209 during peak production of fruit bunches, while maximum $\mathrm{K}$ demand occurred at 88 months after nursery planting, when vegetative growth demand for $\mathrm{K}$ peaked.

(5) Tenera bunches studied here contain $4.74 \mathrm{~kg} \mathrm{~N}, 0.79 \mathrm{~kg} \mathrm{P}, 6.35 \mathrm{~kg} \mathrm{~K}, 1.31 \mathrm{~kg} \mathrm{Mg}$, $2.30 \mathrm{~kg} \mathrm{Ca}$, and $5.9 \mathrm{~g} \mathrm{~B}$ per tonne of fresh fruit bunches.

(6) Total amounts of nutrients required to produce $25 \mathrm{t}$ fresh fruit bunches ha ${ }^{-1}$ year $^{-1}$ were $1.99 \mathrm{~kg} \mathrm{~N}, 0.28 \mathrm{~kg} \mathrm{P}, 3.94 \mathrm{~kg} \mathrm{~K}, 0.42 \mathrm{~kg} \mathrm{Mg}, 0.99 \mathrm{~kg} \mathrm{Ca}$, and $2.5 \mathrm{~g} \mathrm{~B} \mathrm{palm}^{-1}$ year $^{-1}$.

(7) If all leaves produced in a year were pruned off and all its nutrients were recycled, the net amounts of nutrients required to produce $25 \mathrm{t}$ fresh fruit bunches ha ${ }^{-1}$ year $^{-1}$ would be $1.04 \mathrm{~kg} \mathrm{~N}, 0.16 \mathrm{~kg} \mathrm{P}, 1.85 \mathrm{~kg} \mathrm{~K}, 0.26 \mathrm{~kg} \mathrm{Mg}, 0.47 \mathrm{~kg} \mathrm{Ca}$, and $1.3 \mathrm{~g} \mathrm{~B} \mathrm{palm}^{-1}$ year $^{-1}$.

Supplementary Materials: The following are available online at https:/ / www.mdpi.com/article/ 10.3390/agronomy12020426/s1, Figure S1: Leaf production rate of tenera oil palm grown under Malaysian inland environment, Figure S2: Aboveground vegetative biomass of oil palm as quantified in this study and previous studies, Figure S3: Trunk K concentration in relation to palm age and fruit bunch yield in $\mathrm{Ng}$ et al. [2] and this study, Table S1: Concentrations of $\mathrm{N}, \mathrm{P}, \mathrm{K}, \mathrm{Mg}, \mathrm{Ca}$, and $\mathrm{B}$ in spear leaves, rachis, petiole, leaflets, and leaf bases of tenera oil palms of different ages, Table S2: Concentrations of $\mathrm{N}, \mathrm{P}, \mathrm{K}, \mathrm{Mg}, \mathrm{Ca}$, and $\mathrm{B}$ in cabbage, trunk, bole, and roots attached to bole of tenera oil palms of different ages, Table S3: Dry-matter production of mature oil palms in Malaysia, Nigeria, and Ivory Coast, estimated from destructive measurements, Table S4: Nutrient balance sheet prepared for the studied mature (88-238 months old) tenera oil palms grown on Harimau Series soil (Typic Paleudult) in Malaysia.

Author Contributions: Conceptualization, C.S.S. and C.T.B.S.; methodology, C.S.S. and S.A.A.W.; software, C.S.S. and S.A.A.W.; validation, C.S.S., C.T.B.S. and S.A.A.W.; formal analysis, C.S.S. and S.A.A.W.; investigation, C.S.S., C.T.B.S. and S.A.A.W.; resources, C.S.S. and S.A.A.W.; data curation, C.S.S., C.T.B.S. and S.A.A.W.; writing-original draft preparation, C.S.S.; writing-review and editing, C.S.S. and C.T.B.S.; visualization, C.S.S. and C.T.B.S.; supervision, C.T.B.S.; project administration, C.S.S. and S.A.A.W.; funding acquisition, C.S.S. All authors have read and agreed to the published version of the manuscript. 
Funding: This research received no external funding.

Institutional Review Board Statement: Not applicable.

Informed Consent Statement: Not applicable.

Data Availability Statement: Not applicable.

Acknowledgments: The authors would like to acknowledge Sime Darby Plantation Berhad for supporting this research. The authors would also like to acknowledge colleagues and staff at Sime Darby Plantation Research, for their support and cooperation. The authors would like to thank R.H.V. Corley for his critical and valuable comments on the manuscript.

Conflicts of Interest: The authors declare no conflict of interest.

\section{References}

1. Rajanaidu, N.; Kushairi, A. Oil palm planting materials and their yield potential. In Proceedings of the International Society of Oil Palm Breeders Symposium: Yield Potential in Oil Palm II, Phuket, Thailand, 27-28 November 2006.

2. Ng, S.K.; Thamboo, S.; de Souza, P. Nutrient contents of oil palms in Malaya. II Nutrients in vegetative tissues. Malays. Agric. J. 1968, 46, 332-391.

3. $\mathrm{Ng}, \mathrm{S} . \mathrm{K}$. Review of oil palm nutrition and manuring. Scope for greater economy in fertiliser usage. Oléagineux 1977, 32, 197-209.

4. Goh, K.J.; Chew, P.S.; Teoh, K.C. Dry matter production and nutrient budget in the mature oil palm (Elaeis guineensis Jacq.) agroecosystem: III N budget. AAR Confid. Rep. 1997, 3, 39.

5. Goh, K.J.; Chew, P.S.; Teoh, K.C. Dry matter production and nutrient budget in the mature oil palm (Elaeis guineensis Jacq.) agroecosystem: IV P budget. AAR Confid. Rep. 1997, 4, 30.

6. Tarmizi Mohamad, A.; Tayeb Dolmat, M. Nutrient demands of Tenera oil palm planted on inland soils of Malaysia. J. Oil Palm Res. 2006, 18, 204-209.

7. Chew, P.S. Soil resources and plantation agriculture in Malaysia. In Proceedings of the Conference on Peat and Other Soil Factors in Crop Production, Kuala Lumpur, Malaysia, 17-19 April 2007; Jol, H., Ed.; Malaysian Society of Soil Science: Kuala Lumpur, Malaysia, 2007; pp. 1-41.

8. Paramananthan, S. Soil requirements of oil palm for high yields. In Managing Oil Palm for High Yields: Agronomic Principles; Goh, K.J., Ed.; Malaysian Society of Soil Science and Param Agricultural Surveys: Kuala Lumpur, Malaysia, 2000; pp. 18-38.

9. Wahid, M.B.; Simeh, M.A. Issues related to production cost of palm oil in Malaysia. Oil Palm Ind. Econ. J. 2009, 9, 1-12.

10. Darras, K.F.A.; Corre, M.D.; Formaglio, G.; Tjoa, A.; Potapov, A.; Brambach, F.; Sibhatu, K.T.; Grass, I.; Rubiano, A.A.; Buchori, D.; et al. Reducing fertilizer and avoiding herbicides in oil palm plantations-Ecological and economic valuations. Front. For. Glob. Chang. 2019, 2, 65. [CrossRef]

11. Corley, R.H.V.; Tinker, P.B. The Oil Palm, 5th ed.; John Wiley \& Sons: Oxford, UK, 2016; pp. 341-342.

12. Foster, H.L.; Chang, K.C. The diagnosis of the nutrient status of oil palms in West Malaysia. In International Developments in Oil Palm; Earp, D.A., Newall, W., Eds.; Incorporated Society of Planters: Kuala Lumpur, Malaysia, 1977; pp. $290-312$.

13. Foster, H.L.; Prabowo, N.E. Overcoming the limitations of foliar diagnosis in oil palm. In Proceedings of the 2002 International Oil Palm Conference, Bali, Indonesia, 8-12 July 2002; Indonesian Oil Palm Research Institute: Sumatera Utara, Indonesia, 2002.

14. Foster, H.L.; Prabowo, N.E. Partition and transfer of nutrients in the reserve tissues and leaves of oil palm. In Proceedings of the Workshop on Nutrient Needs in Oil Palm, Singapore, 17-18 October 2006.

15. Rees, A.R.; Tinker, P.B. Dry-matter production and nutrient content of plantation oil palms in Nigeria. I. Growth and dry-matter production. Plant Soil 1963, 19, 19-32. [CrossRef]

16. Corley, R.H.V.; Gray, B.S.; Ng, S.K. Productivity of the oil palm (Elaeis guineensis Jacq.) in Malaysia. Exp. Agric. 1971, 7, 129-136. [CrossRef]

17. Tinker, P.B.; Smilde, K.W. Dry-matter production and nutrient content of plantation oil palms in Nigeria. II. Nutrient content. Plant Soil 1963, 19, 350-363. [CrossRef]

18. Teoh, K.C.; Chew, P.S. Potassium in the oil palm eco-system and some implications to manuring practice. In Proceedings of the 1987 International Oil Palm Conference Progress and Prospects, Kuala Lumpur, Malaysia, 23-26 June 1987; Halim Hassan, A., Ed.; Palm Oil Research Institute of Malaysia: Bangi, Malaysia, 1988; pp. 277-286.

19. Prabowo, N.E.; Foster, H.L.; Silalahi, A.J. Recycling oil palm bunch nutrients. In Proceedings of the Oil Palm Conference, Bali, Indonesia, 19-23 June 2006.

20. Donough, C.R.; Cahyo, A.; Oberthür, T.; Ruli, W.; Gerendas, J.; Gatot, A.R. Improving nutrient management of oil palms on sandy soils in Kalimantan using the $4 \mathrm{R}$ concept of IPNI. In Proceedings of the International Oil Palm Conference, Bali, Indonesia, 17-19 June 2014.

21. Goh, K.; Gan, H.; Kee, K.; Chew, P.; Teoh, K. Boron Nutrition and Boron Application in Crops. In Advances in Plant and Animal Boron Nutrition; Xu, F., Ed.; Springer: Dordrecht, The Netherlands, 2007.

22. Tiemann, T.T.; Donough, C.R.; Lim, Y.L.; Härdter, R.; Norton, R.; Tao, H.H.; Jaramillo, R.; Satyanarayana, T.; Zingore, S.; Oberthür, T. Feeding the palm: A review of oil palm nutrition. Adv. Agron. 2018, 152, 149-243. 
23. Paramananthan, S. Soils of Malaysia-Their Characteristics and Identification; Academy of Sciences: Kuala Lumpur, Malaysia, 2000; Volume I, pp. 436-437.

24. Lim, K.H.; Goh, K.J.; Kee, K.K.; Henson, I.E. Climatic requirements of oil palm. In Agronomic Principles and Practices of Oil Palm Cultivation; Goh, K.J., Chiu, S.B., Paramananthan, S., Eds.; Agricultural Crop Trust: Petaling Jaya, Malaysia, 2011 ; pp. 3-48.

25. Matejovic, I. Determination of carbon, hydrogen, and nitrogen in soils by automated elemental analysis (dry combustion method). Commun. Soil Sci. Plan. 1993, 24, 17-18. [CrossRef]

26. Varley, J.A. Automatic methods for the determination of nitrogen, phosphorus and potassium in plant material. Analyst 1966, 91, 119-126. [CrossRef]

27. SIRIM. SIRIM Recommended Methods for Plants Analysis, 1st ed.; SIRIM: Shah Alam, Malaysia, 1980.

28. John, M.K.; Chuah, H.H.; Neufeld, J.H. Application of improved azomethine-H method to the determination of boron in soils and plants. Anal. Lett. 1975, 8, 559-568. [CrossRef]

29. Paine, C.E.T.; Marthews, T.R.; Vogt, D.R.; Purves, D.; Rees, M.; Hector, A.; Turnbull, L.A. How to fit nonlinear plant growth models and calculate growth rates: An update for ecologists. Methods Ecol. Evol. 2012, 3, 245-256. [CrossRef]

30. Nazeeb, M. Investigations on Optimal Planting Density for Oil Palm (Elaeis guineensis Jacq.) in Peninsular Malaysia. Ph.D. Thesis, University of Malaya, Kuala Lumpur, Malaysia, 2000.

31. Henson, I.E.; Chai, S.H. Analysis of oil palm productivity. II. Biomass, distribution, productivity and turnover of the root system Elaeis 1997, 9, 78-92.

32. Corley, R.H.V.; Hardon, J.J.; Tan, G.Y. Analysis of growth of the oil palm (Elaeis guineensis Jacq.). I. Estimation of growth parameters and application in breeding. Euphytica 1971, 20,307-315. [CrossRef]

33. Ng, S.K.; Thamboo, S. Nutrient contents of oil palms in Malaya. I. Nutrients required for reproduction: Fruit bunches and male inflorescence. Malays. Agric. J. 1967, 46, 3-45.

34. Khalid, H.; Zin, Z.Z.; Anderson, J.M. Quantification of oil palm biomass and nutrient value in a mature plantation. I. Aboveground biomass. J. Oil Palm Res. 1999, 11, 23-32.

35. Syahrinudin. The Potential of Oil Palm and Forest Plantations for Carbon Sequestration on Degraded Land in Indonesia; Ecology and Development Series 28; Cuvillier: Gottingen, Germany, 2005.

36. Legros, S.; Mialet-Serra, I.; Caliman, J.P.; Clement-Vidal, A.; Siregar, F.A.; Widiastuti, L.; Jourdan, C.; Dingkuhn, M. Carbohydrates reserves in 9 years old oil palm: Nature, distribution and seasonal changes. In Proceedings of the International Oil Palm Conference on Optimum Use of Resources: Challenges and Opportunities for Sustainable Oil Palm Development, Bali, Indonesia, 19-23 June 2006.

37. Lewis, K.; Rumpang, E.; Kho, L.K.; McCalmont1, J.; Teh, Y.A.; Gallego-Sala, A.; Hill, T.C. An assessment of oil palm plantation aboveground biomass stocks on tropical peat using destructive and non-destructive methods. Sci. Rep. 2020, 10, 2230. [CrossRef]

38. Dufrene, E. Photosynthese, consommation en eau et modelisation de la production chez le palmier a huile (Elaeis guineensis Jacq.). Ph.D. Thesis, University of Paris-Sud, Orsay, France, 1989.

39. Paramananthan, S. Peat soils of Malaysia: Their extent, characteristics, mapping and classification. Planter 2003, 89, 737-757.

40. Dolmat, M.; Hamdan, A.B.; Zulkifli, H.; Ahmad Tarmizi, M. Fertiliser requirement of oil palm on peat-An update. In Proceeding of the 1996 PORIM International Palm Oil Congress-Agriculture Conference, Kuala Lumpur, Malaysia, 23-28 September 1996; Ariffin, D., Mohd Basri, W., Mohd Tayeb, D., Paranjothy, K., Rajanaidu, N., Cheah, S.C., Chang, K.W., Ravigadevi, S., Eds.; PORIM: Bangi, Malaysia, 1996; pp. 131-141.

41. Hartley, C.W.S. The Oil Palm, 3rd ed.; Longman: London, UK; New York, NY, USA, 1988.

42. Nouy, B.; Baudouin, L.; Djegui, N.; Omore, A. Oil palm under limiting water supply conditions. Plant. Rech. Développement 1999, $6,31-45$.

43. Ollivier, J.; Flori, A.; Cochard, B.; Amblard, P.; Turnbull, N.; Syahputra, I.; Suryana, E.; Lubis, Z.; Surya, E.; Sihombing, E.; et al. Genetic variation in nutrient uptake and nutrient use efficiency of oil palm. J. Plant Nutr. 2017, 40, 558-573. [CrossRef]

44. Goh, K.J.; Chew, P.S.; Kee, K.K. K Nutrition for Mature Oil Palm in Malaysia, IPI Research Topics No.17; International Potash Institute: Basel, Switzerland, 1994.

45. Henson, I.E.; Betitis, T.; Tomda, Y.; Chase, L.D. The estimation of frond base biomass (FBB) of oil palm. J. Oil Palm. Res. 2012, 24, $1473-1479$.

46. Henson, I.E.; Chang, K.C. Modelling oil palm nutrient demand, nutrient turnover and nutrient balance. MPOB Technol. 2007, 30 , 1-66.

47. Taub, D.R.; Wang, X. Why are nitrogen concentrations in plant tissues lower under elevated $\mathrm{CO}_{2}$ ? A critical examination of the hypotheses. J. Integr. Plant Biol. 2018, 50, 1365-1374. [CrossRef] [PubMed]

48. Yuan, Z.; Liu, W.; Niu, S.; Wan, S. Plant nitrogen dynamics and nitrogen-use strategies under altered nitrogen seasonality and competition. Ann. Bot. 2007, 100, 821-830. [CrossRef] [PubMed]

49. Foong, S.F. Potential evaporation, potential yield and leaching losses of oil palm. In Proceeding of the 1991 PORIM International Palm Oil Conference-Agriculture Conference, Kuala Lumpur, Malaysia, 9-14 September 1991; Yusof, B., Jalani, B.S., Cheah, S.C., Henson, I.E., Norman, K., Paranjothy, K., Rajanaidu, N., Mohd Tayeb, D., Ariffin, D., Eds.; PORIM: Bangi, Malaysia, 1993 ; pp. $105-119$.

50. Kee, K.K.; Chew, P.S. Nutrient losses through surface runoff and soil erosion-Implications for improved fertilizer efficiency in mature oil palms. In Proceeding of the 1996 PORIM International Palm Oil Congress-Agriculture Conference, Kuala Lumpur, Malaysia, 23-28 September 1996; Ariffin, D., Mohd Basri, W., Mohd Tayeb, D., Paranjothy, K., Rajanaidu, N., Cheah, S.C., Chang, K.W., Ravigadevi, S., Eds.; PORIM: Bangi, Malaysia, 1996; pp. 153-169. 